\title{
The Importance of Accuracy in the Use of Grammatical Terms and Concepts in the Description of the Distinctive Properties of Plains Algonquian Languages
}

\author{
Avelino Corral Esteban \\ Universidad Autónoma de Madrid
}

\begin{abstract}
Correspondence concerning this article should be addressed to Avelino Corral Esteban, Departamento de Filología Inglesa, despacho 205 VI-bis Facultad de Filosofía y Letras,Campus de Cantoblanco, Universidad Autónoma de Madrid, Madrid 28049, Spain. E-mail: avelino.corral@uam.es
\end{abstract}

\begin{abstract}
The interest in linguistic typology and the study of the syntax-semantics-pragmatics interface in a number of languages - especially Native American languages - has led to the observation that some languages cannot be accurately described if we use the grammatical terms and concepts commonly applied to the analysis of extensively studied languages, as certain grammatical properties of one language may not be equivalent to those of another and, consequently, require a different treatment. Thus, by adopting a holistic comparative perspective deriving from all areas of grammar, the article aims to reveal the distinctive features that Plains Algonquian languages such as Cheyenne / Tsèhésenėstsestotse (Montana and Oklahoma, USA), Blackfoot / Siksiká, Kainai, and Pikani, (Montana, USA; Alberta, Canada), Arapaho / Hinónóeitíít (Wyoming and Oklahoma, USA), and Gros Ventre / White Clay or Atsina / Aaniiih (Montana, USA) display when compared with Indo-European languages such as English, Spanish, French or German. The subsequent examination of these data will provide examples of terms and concepts that are typically used in traditional grammatical descriptions, but that do not serve to characterize the grammar of these Native American languages accurately. Finally, the article will propose alternative terms and concepts that might describe the distinctive grammatical properties exhibited by these languages more adequately.
\end{abstract}

Keywords: terms and concepts, grammar, terminological accuracy, Plains Algonquian languages, language universals

Grammatical terminology provides an economic and precise way of referring to grammatical elements within a language and offers the possibility to compare languages in order to prove whether the label for a concept in a language has been applied to what is perceived as the semantic or functional equivalent of the original concept in another language; or, conversely, whether, the semantic or functional value is realized quite differently in the different languages and therefore the use of the term is, in at least one of the languages, inaccurate.

Given that languages are not completely equivalent to each other, it seems plausible to assume that the metalanguage that serves to characterize their grammar will inevitably have to vary crosslinguistically. This study, therefore, aims to elucidate whether a number of grammatical properties of Plains Algonquian languages can be adequately described by adopting the same terms that have been traditionally used for the description of other better-known languages.

This research thus has two different but related aims - one grammatical and the other terminological - as the accurate use of a number of grammatical terms and concepts to describe the grammar of the Plains Algonquian languages is examined based on an analysis of some of the grammatical properties that distinguish these minority languages from the most widely studied languages in the world - English or Spanish, for example. Subsequently, where necessary, an alternative denomination will be proposed for these grammatical features with the aim of characterizing the different syntactic, semantic, lexical, phonological, morphological, and discourse-pragmatic data in Plains Algonquian languages in a more effective way.

The article is organized as follows: section 1 
covers the fundamental issue of the universality of grammatical relations such as subject and object, by taking into account the way that semantic roles are neutralized in these languages. Section 2 offers an account of the dichotomy between semantic and syntactic valence by describing how the concept of specificity influences the argument structure, thereby affecting whether an element is considered as an argument or adjunct. Section 3 follows with a detailed analysis of the classification of words into different parts of speech in these Algonquian languages, reflecting two different views concerning the identification of the number of types of category. Section 4 explores both traditional and contemporary analyses of prosodic systems in order to examine the reasons why Plains Algonquian languages are referred to as stress, pitch accent or tone systems. Section 5 examines the appropriateness of the denomination of obviation as a type of case and section 6 provides arguments for the assumption that the information structure in these languages would indeed be better characterized by understanding the traditional distinctions of theme and rheme or topic and focus in a way that takes into account the paramount importance given by the addresser to what the addressee considers most relevant. Finally, the conclusion offers a brief summary of the paper's main findings.

A substantial number of books have been written to describe the grammar of Algonquian languages in general, such as Bloomfield's (1946) Algonquian and Goddard's (1979) Comparative Algonquian. To characterize more particularly the grammar of Plains Algonquian languages, the most comprehensive include Salzmann's (1963) Sketch of Arapaho Grammar, Uhlenbeck's (1978) A Concise Blackfoot Grammar, Leman's (1980b) A Reference Grammar of the Cheyenne Language, Frantz's (1997) Blackfoot Grammar, Cowell et al.'s (2004) Gros Ventre Student Grammar, and Cowell \& Moss's (2008) The Arapaho Language. Likewise, a large and growing body of literature has investigated different aspects of the morphosyntax, semantics, and phonology of these languages, as illustrated by the articles written by Bliss on Blackfoot, Frantz on Blackfoot and Cheyenne, Goddard on Arapaho, Cheyenne and Gros Ventre, or Leman on Cheyenne, among others.

However, apart from these studies, no work has been found that explore the accuracy in the use of grammatical terminology for the description of the distinctive aspects of the grammar shown by the Plains Algonquian languages in particular. Despite this, I do not claim any originality with my study, as I am aware that, on the one hand, the grammatical phenomena examined in this paper have already been described separately in different studies and, on the other hand, the relationship between the grammatical concepts dealt with in this article and the grammatical terminology that seemingly reflects faithfully their value may already have been addressed by a large number of scholars working within different theoretical frameworks. Consequently, my only aim is to reveal the grammatical distinctiveness of these languages and highlight the importance of finding terms that ensure accuracy in their description.

\section{Materials and Methods}

On the one hand, this research could be considered a multilingual ad hoc terminological study since it deals with the designation of a limited number of concepts and their labelling in a specific grammatical domain. More specifically, it attempts to analyse the concepts used in the description of some grammatical aspects of the Plains Algonquian languages, identify the terms that could be assigned more properly to these concepts, establish a possible correspondence between the concepts and terms in these languages, and propose new terms if the existing ones in the literature do not reflect faithfully the specific concepts.

On the other hand, as mentioned above, this study is not a pure terminological work since, in addition to being a study of grammatical concepts and their terminological labels, it is also aimed at giving a detailed account of a number of grammatical phenomena. Thus, in order to achieve the grammatical objective of this study, all of the existing literature was explored in order to understand both the core and peripheral grammar of the Plains Algonquian languages and, after comparing their grammatical properties of these languages with those of the most-studied languages such as English, Spanish, French or German, various distinctive language units - each of them of a different nature (e.g., morphological, syntactic, semantic, lexical, phonological and discourse-pragmatic) - were selected and analysed in depth. Given this first part of the study reveals the distinctive properties that Plains Algonquian languages display and that these grammatical features cover all areas of the language, it could be considered to take a holistic methodological perspective.

Following Mielke and Jeff (2008) and Haspelmath (2009), the different grammatical properties of these languages were described and explained by employing a framework-free approach, that is to say, without building upon a specific theoretical framework. This dependence on a model for linguistic description which is probably based on one of the most-widely studied languages in the world could place the description of other minority languages like Arapaho, Blackfoot, Cheyenne, or Gros Ventre into a straight-jacket. In 
other words, the study could inevitably commit the error of carrying over concepts that have been applied to the analysis of languages such as English or Spanish grammar to these Native American languages, which is, oddly enough, one of the causes of the inaccuracy of some grammatical terms obviating the fact that they may present different grammatical properties and therefore require a different treatment. Consequently, the methodology followed consisted in selecting and subsequently describing in their own terms the most distinctive grammatical phenomena displayed by these languages, such as the notion of grammatical functions, the argument/adjunct distinction, the number of categories, the type of prosodic system, the notion of grammatical case and the arrangement of sentence constituents. The examples from the Plains Algonquian languages used throughout this paper to illustrate the various grammatical concepts come mainly from the following sources: from published studies, especially Cowell et al. (2004), Cowell \& Moss (2008), Frantz (1991), Frantz \&and Russell (1995), Leman (1991), and Leman et al. (2006), and native speaker elicitation.

Finally, in an attempt to comply with the terminological aim, I examined the relationship between the different grammatical concepts examined in Arapaho, Blackfoot, Cheyenne and Gros Ventre and the terms that are traditionally used to describe concepts that appear to have a similar semantic value in other better-known languages in order to decide if they could also serve to characterize the grammatical concepts in the Plains Algonquian languages appropriately. More specifically, after reviewing the existing literature on grammatical terminology, I examined different terms that have been traditionally used to label similar concepts in other languages in order to decide which was the term that described more adequately the grammatical properties shown by each of these phenomena in these Native American languages. It is therefore in this final step that I had to make reference to the most influential theoretical frameworks - both formal and functional -since many of the terms (e.g., Privileged Syntactic Argument, argument-adjunct, etc.) suggested in some of these approaches reflected faithfully the grammatical properties exhibited by the Plains Algonquian languages and, consequently, there was no need to coin a new term for them.

This section is divided into a number of subsections, which correspond to each of the grammatical properties that distinguish Plains Algonquian languages, such as Arapaho, Blackfoot, Cheyenne and Gros Ventre, from the most widely studied languages in the world. Each of these sub-sections will offer a description of a distinctive grammatical phenomenon displayed by these languages, which will help us to decide what term can be used to designate more accurately the grammatical concept involved in each of the phenomena. Subsequently, in the concluding section of the paper, an alternative denomination will be proposed for these grammatical features that have not been properly defined with the aim of offering a more appropriate characterization of the grammatical properties displayed by these Native American languages.

\section{Results and Discussion}

\section{Grammatical Relations}

"Grammatical relations", also commonly referred to as "grammatical functions" or "syntactic functions", is a linguistic term traditionally used to refer to the functional relationships between constituents in a clause.Most grammatical theories - whethergenerative grammar, functional grammar or cognitive grammar often acknowledge these syntactic relations and rely heavily on them in order to describe a plethora of grammatical phenomena, even considering them to be universal. ${ }^{1}$ These grammatical relations are illustrated in traditional grammar by concepts such as "subject", "direct object", and "indirect object"

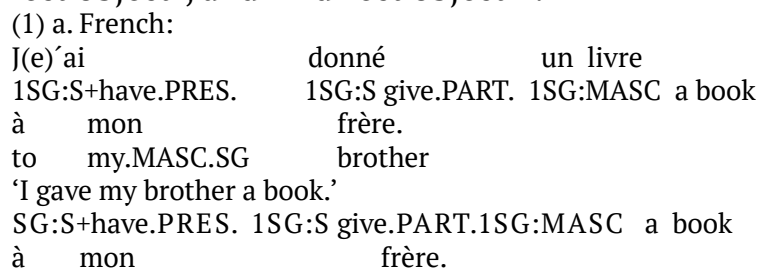

${ }^{1}$ For a detailed account, see Comrie (1978), Dixon (1979), Palmer (1994), Givón (1995), and Dryer (1997).

2 Abbreviations used in this paper: (1) - first person, (2) - second person, (3) - third person or proximate singular agreement, (4) - fourth person or proper obviative agreement, fifth person or further obviative agreement, (11) - first person, (22) - second person, (33) - third person plural agreement, (I) - inanimate singular agreement - (II) - inanimate plural agreement, $\mathrm{X}$ unspecified agent agreement; A - agent semantic role, ABS absolutive case, ACC - accusative case, ANAPH - anaphoric, ASP - aspect, BEN - beneficiary semantic role, CLM - complementizer, DAT - dative case, DEIC - deictic, DERIV - derivative affix, DIM diminutive affix, DITR - ditransitive verb, DUB - dubitative mode, D3P - distinct third person, ERG - ergative case, FAI - animate intransitive final stem, FEM - feminine genre, FUT - future, I - initial stem, ITER - iterative mode, GEN - genitive case, IC initial change, IF - Illocutionary Force, INSTR - instrumental case, IO - indirect object, LOC - locative case, MASC- masculine genre, $\mathrm{M}$ - medial stem, MED - mediate mode, MODAL - modal particle, $\mathrm{N}$ - noun, NEG - negation, NEUT - neuter genre, NOM - nominative case, NP - noun phrase, OBV - obviative marking, $\mathrm{P}$ - patient semantic role, PART - past participle, PAST - past, PP prepositional phrase, PRES - present, PROX - proximate marking, REDUP - reduplication, S- subject, SG - singular number, STAT stationary, PL - plural number, TRNS - translocative, V - verb, VAI - animate intransitive verb, VII - intransitive inanimate verb, VTA - transitive animate verb, VTI - transitive inanimate verb. 
to my.MASC.SG brother

'I gave my brother a book.'

b. Spanish:

Yo $(l e)^{3}$ dí a mi hermano un libro.

$1 \mathrm{SG}: S$ 3SG:IO give.PAST.1SG:S to my brother a book

'I gave my brother a book.'

Despite the fact that each distinct grammatical theory aims to avoid concrete definitions of notions such as "subject" or "object" - most syntactic frameworks treat them as primitive concepts - the important role they have assumed in linguistic theorizing has led to the seeking of useful strategies as a means of distinction between them (Conner, 1968; Comrie, 1989; Biber et al., 1999).

Distinguishing between these grammatical relations appears to be a relatively simple task if we consider them to be equivalent to thematic or semantic roles such as agent or patient. In the four examples given above there is a first person singular subject which performs the action, a direct object NP, represented by 'un libro' and 'un livre' in Spanish and French respectively, which is acted upon by the subject, and an indirect object ${ }^{4} \mathrm{NP}$, represented by 'mi hermano' and 'mon frère', benefits from the action receiving the direct object.

However, if we look closer - for example when analyzing sentences including a verb in the passive (e.g., 'My brother was given a book by me.' or 'A book was given to my brother by me.'), an ergative verb (e.g., 'The boat sank.'), or an unaccusative verb (e.g., 'An accident occurred yesterday.'), that is, constructions where the frequent correlation between the grammatical relations of subject and object and the semantic roles of agent and patient is absent ${ }^{5}$ - it quickly becomes clear that there is no easy way of identifying the subject and object and that it is even very difficult to find a theoretically satisfying definition for these notions, the result being usually less than clear and, therefore, controversial.

In another common definition of the concept "grammatical relations" the role played by inflectional morphology is emphasized. In languages with morphological case systems, that is nominativeaccusative (e.g., German, Latin, etc.) or ergativeabsolutive (e.g., Basque, Georgian, etc.), the subject, direct object, and indirect object are identified by their

\footnotetext{
${ }^{3}$ Even though not strictly necessary, it is possible to use both indirect object pronouns (e.g., le) and indirect object noun phrases (e.g., 'a mi hermano') together in the same sentence in Spanish. In fact, this is very common, especially for reasons of clarity or emphasis.

4 The prepositional object introduced by à has traditionally been called “complément d'objet indirect” in French grammar.

5 While grammatical relations and thematic relations (= thematic roles or semantic roles) belong to different levels of grammar, namely syntax and semantics respectively, acknowledging the correspondence between both, for example between subjects and agents and between objects and patients or themes, can be helpful to define the term 'grammatical relation' semantically.
}

case markers, namely nominative, accusative, and dative in the former (2a), and ergative, absolutive and dative in the latter $(2 b)$ :

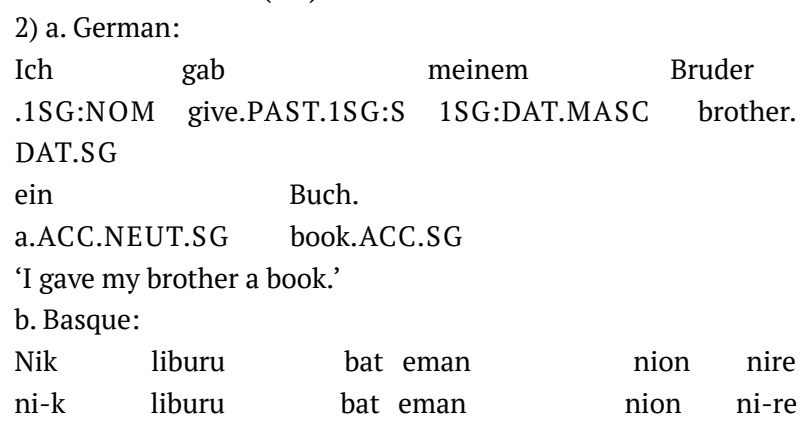

1SG-ERGbook.ABS a.ABS give.PAST 3SG:DAT 1SG-GEN anaiari.

anaia-(a)ri

brother-SG:DAT

'I gave my brother a book.'

However, the usefulness of inflectional morphology is often very limited. For instance, it does not help much in languages that lack morphological cases almost entirely - English, Spanish or French, for example. There are also constructions, such as those involving raising-to-object (e.g., 'I want him to leave.') or the presence of oblique or quirky case-marked subjects in Icelandic, where the expected correspondence between nominative and agent and between accusative and patient do not occur.

Another property sometimes considered typical of subjects is agreement. Many languages -English, French, German or Spanish for example - require their verbs to agree with only one argument, which is referred to as the subject. However, there are many other languages, such as Basque, Georgian or Mohawk, which are commonly referred to as polypersonal languages, whose verbs agree with more than one argument in a transitive construction.

Finally, another frequent means used to define syntactic relations is in terms of the syntactic configuration (Marantz, 1981). The subject is defined as the verbal argument that appears outside the canonical finiteverb phrase, agreeing with the finite verb in person and number in most languages (e.g., English, Spanish, French, Italian, German, etc.), whereas the object is taken to be the verbal argument that appears inside the verb phrase. ${ }^{6}$ This configurational understanding of grammatical relations works relatively efficiently in terms of distinguishing between subject and object. ${ }^{7}$ It may run into difficulty in existential constructions (e.g., 'There are a lot of women at the party.'), where the element occupying the preverbal position does not agree with the verb and, consequently, should

\footnotetext{
${ }^{6}$ This approach does not appear to work as well for other grammatical relations, such as attributes, prepositional arguments, etc.

${ }^{7}$ I obviate the structural distinction between different kinds of object.
} 
not be considered as the subject, and the element that appears post-verbally does not appear to behave like a prototypical object as it agrees with the verb and should therefore be granted subject status. Furthermore, this approach does not appear to work as well for languages often referred to as non-configurational such as Warlpiri, whose subjects and objects do not appear to be distinguishable in terms of structure position (Hale, 1983). ${ }^{8}$ The difficulty in defining grammatical relations in terms of thematic, configurational or morphological criteria can be explained by the fact that notions like "subject" or "object" are relational, so that they can only exist if they appear in a context (e.g., a sentence) where they are related to each other as well as to a particular action or process (Dryer, 1995). Most work in current theoretical syntax overcomes this problem by pursuing an all-encompassing approach that posits prototypical traits (Keenan, 1976; Dixon, 1979; Hopper \& Thompson, 1980; Dowty, 1991; Comrie, 1989; Givón, 1995; Malchukov, 2005). The prototypical subject has a cluster of thematic, configurational, and/ or morphological traits (agent, pre-verbal position, nominative case), with the same being true of the prototypical object (patient, post-verbal position, accusative case) and other verb arguments. ${ }^{9}$ Across languages (e.g., ergative, split-infinitive, direct-inverse, etc.) and constructions within a language (e.g., passive, existential, fronting, etc.), there are many cases where a given subject argument may not be a prototypical subject, but has enough subject-like traits to be granted subject status. Similarly, a given object argument may not be prototypical in one way or another, but if it has enough object-like traits, then it receives the status of object nonetheless.

This consideration of grammatical relations as clusters of traits rather than syntactic elements per se may help to explain the fact that concepts such as subject and direct object have been traditionally considered as innate categories of Universal Grammar (Comrie, 1978; Dixon, 1979). However, evidence from Algonquian languages would appear to suggest that not all languages necessarily have grammatical relations in addition to semantic roles (Schachter, 1976; Foley \& van Valin, 1977 and 1984; Dryer, 1997; van Valin \& LaPolla, 1997; van Valin, 2005; Kibrik, 2009), which are universal, and that in languages where the existence of a non-semantic relation is empirically motivated, the syntactic function posited need not have the same properties. ${ }^{10}$

\footnotetext{
8 In formal theory, "subject" and "object" are typically considered syntactic positions that constituents may reach through the application of transformational rules.

${ }^{9}$ For a more comprehensive list of subject properties, see Keenan (1976) and Falk (2006, p. 6).

10 van Valin (2005, pp. 90-93) provides robust evidence for the assumption that grammatical relations are not universal by analyzing examples involving an unrestricted neutralization in Acehnese.
}

Unlike languages like English, where the distinction between two or more semantic roles is neutralized for syntactic purposes - the verb always agrees with an element that is referred to as "subject" regardless of whether it is actor, patient, experiencer, etc. (e.g., 'The teacher has sung.', 'The teacher has fainted.', 'The teacher has cried.', etc.) - Plains Algonquian languages are examples of languages in which this kind of restricted neutralization is not found:

\section{(3) Blackfoot:}

Kitsikákomimmo.

kit-waakomimm-o

(2)-love.VTA-1:2

'I love you (sg).'

(4) Blackfoot:

Kitsikákommimoki.

kit-waakomimm-oki

(2)-love.VTA-2:1

'You (sg) love me.'

(5) Cheyenne:

Néméhotätse.

né-méhot-àtse

(2)-love.VTA-1:2

'I love you (sg).'

(6) Cheyenne:

Néméhoxe.

né-méhot-e

(2)-love.VTA-2:1

'You (sg) love me.'

The syntactic neutralization taking place in Algonquian languages is reflected, by contrast, in the coding of a personal prefix. ${ }^{11}$ This prefix in

${ }^{11}$ In Arapaho and Gros Ventre, however, it is not always possible
to discern the verbal prefix and therefore the privileged syntactic
argument owing to the presence of "initial change" (IC), an
inflectional process typical of Algonquian languages whereby the
first element of a verbal form, namely the first vowel of a preverb or, in the absence of a preverb, of the verb stem itself, is modified:

E.g.: Arapaho:

a. Biixoo3e3en.

IC+bixoo3-é3en

(2)+love.VTA-1:2

'I love you (sg).'

b. Biixooxín.

IC+bixoo3-ín

(2)+love.VTA-2:1

'You (sg) love me.'

E.g.: Gros Ventre:

a.Nii'áaanibáan'o.

ic+ni'áaanib-áan's

(2)-love.vta-1:2

'I love you (sg).'

b. Nii'áaanibei'aan'o.

ic+ni'áaanib-ei'aan's

(2)-love.vta-2:1

'You (sg) love me.'

As is evidenced from these examples, although the initial change originated in, and is characteristic of, the conjunct order, it also occurs in the independent order in Arapaho when there is no prefix before the verb (and it is not a command); otherwise, the verb remains normal. 
Algonquian languages does not depend on a specific semantic role but on a person-salience hierarchy whereby the second person is considered the highestranking person. The hierarchy $2^{\text {nd }} .>1^{\text {st }} .>3^{\text {rd }} .>4^{\text {th }} .>$ Inanimate is related to the discourse-pragmatic status of the participants involved in the communicative act: local participants (i.e., first and second person) are ranked over third persons (i.e., proper third person or proximate, obviative and inanimate) since the former are considered to have more salience, animacy, and topicality than the latter. Consequently, in these languages, the second person is regarded as the most pragmatically prominent salient person in a situation, which means that whenever a second person participant is involved in a clause, regardless of whether it has the semantic role of agent or patient - or to put it differently, whether the grammatical function is subject or object - the verb will begin with the second person prefix.

As evidenced from Blackfoot (3 and 4) and Cheyenne (5 and 6) the form of the personal prefix (e.g., kit- in Blackfoot) remains invariable regardless of the syntactic function or semantic role played by the participants in the clause. The coding of the participants involved in the action is also realized syntactically through a portmanteau suffix marking its person, number, and obviation as well as the direction of the action, i.e., direct vs. inverse, (e.g., - $o$ and -oki in Blackfoot). Consequently, the formation of the prefix entails a neutralization of semantic roles based on discourse-pragmatic factors and there are, therefore, no grounds for positing the existence of grammatical relations such as subject or object in addition to semantic roles. Perhaps, we could argue that the prefix marks an agent subject in direct constructions and a patient subject in inverse constructions, the object lying unmarked in both constructions. There is no apparent reason - perhaps only the denomination of "direct" and "inverse" - to exclude the other alternative, however, namely the fact that the prefix marks an agent object in the former and a patient object in the latter. Rather, it would seem reasonable to conclude that the existence of this prefix marking the person of the most prominent participant in a particular context appears to provide evidence for the existence of a single grammatical relation (Dryer, 1997, p. 131).

This situation led the Role and Reference Grammar framework (RRG) to introduce the concept of "privileged syntactic argument" (PSA) (van Valin, 1993, pp. 65-72; 2005, pp. 94-106; van Valin \& LaPolla, 1997, pp. 274-285), a construction-specific relation that can be defined as a restricted neutralization of semantic roles and pragmatic functions for syntactic purposes" (van Valin, 2000, p. 67). It can be claimed, therefore, that the semantic roles and pragmatic functions in these languages are neutralized for syntactic purposes, namely the need to attach a prefix to the verbal complex, which is determined by the discoursepragmatic properties of the participants involved according to the person - salience hierarchy. Thus, these languages could be said to have a pragmatically influenced PSA as their only grammatical relation.

A different approach could be adopted if we agree with Falk's (2006) consideration of the concept of "subject". According to him, the term "subject" represents an intersection of two different, though closely related, grammatical functions: 1) GF, the relationally most prominent argument function (the other less prominent one(s) being characterized as $\mathrm{OBJ}$ ), and 2) PIV (pivot), an element playing a special syntactic role (e.g., connecting clauses, in control constructions, etc.). ${ }^{12}$ Thus, if we take into account the fact that the argument cross-referenced by the prefix in the verbal complex of an Algonquian clause has some sort of discourse-level prominence - it is generally the most prominent participant according to the personsalience hierarchy - and that the prefix is a syntactic position occupied by only one of the arguments in a transitive context, then a direct construction would reflect a harmonic or unmarked alignment between GF and PIV (i.e., the GF would correspond to the agent) and an inverse construction would show a non-harmonic or marked association since it would establish a correlation between GF and PIV (i.e., the GF would correspond to the patient).

\section{Argument Structure and Transitivity}

\footnotetext{
12 I have not been able to find a context involving complex constructions where the prefix could be said to have a role analogous to that of PIV, if we adhere to Falk's consideration of this grammatical function. To my knowledge, constructions such as clausal coordination, long distance extraction and long distance agreement in Plains Algonquian languages do not seem to be subject to the presence of a pivotal element. An instance of long-distance extraction in Blackfoot is included to support this assumption:

E.g.: Blackfoot: a. Ana Rosie nitáísstaak niná́hlsspommowahsi more prominent in (a) and the less prominent in (b)) agrees with the matrix verb in a long-distance agreement construction.
} 
Most theories concerning syntax and semantics acknowledge the "argument" vs. "adjunct" distinction as an innate property of Universal Grammar. This distinction serves to explore the two different types of relation that the clausal constituents can have with respect to the predicate. Thus, the term "argument" traditionally refers to a constituent that helps complete the meaning of a predicate, whereas an "adjunct" is generally defined as a part of the clause that provides further details of an event so that its presence is not essential for the grammaticality of the sentence. ${ }^{13}$ While the terminology used to refer to these concepts sometimes varies ${ }^{14}$, the distinction is generally believed to exist in all languages, as the basic analysis of the syntax and semantics of clauses relies heavily on this differentiation.

According to the valence or valency theory, the area of grammar that explores the nature of predicates and their arguments and adjuncts, predicates have a particular valence, which determines the number and type of argument that can or must appear in a specific context. Thus, predicates can take one, two, or three arguments and a predicate and its arguments form a predicate-argument structure. Regarding the syntactic realization of these semantic categories, it is important to note that, while the discussion of predicates and arguments is mostly associated with lexical verbs and noun phrases, other syntactic categories can also be construed as predicates (e.g., nominal or adjectival predicates) and as arguments (e.g., prepositional or clausal arguments). Finally, adjuncts are normally realized syntactically by means of prepositional and adverbial phrases, noun phrases or clauses. For instance:

(7) German:

Ich trank Milch gestern

1SG:NOM drink.PAST.1SG:S milk.ACC.FEM.SG yesterday in der Schule.

in the.DAT.FEM.SG school.DAT.FEM.SG

'I drank milk yesterday at school.'

This sentence contains a verbal predicate, in the form of the corresponding term for 'drink', and two arguments, namely a first person singular personal pronoun being the subject argument, and a noun phrase represented by 'milk', which functions as the object argument. Furthermore, each example includes two adjuncts, that is 'yesterday' and 'at school', providing additional information that is not necessary to complete the meaning of the predicate. One key difference between arguments and adjuncts is that the appearance of a given argument is obligatory, so when we attempt to omit them, the result is unacceptable

\footnotetext{
${ }^{13}$ See Tesnière (1969, p. 128), Kroeger (2004, p. 9ff), among others.

${ }^{14}$ Arguments are also commonly referred to as complements or actants depending on the type of grammar; adjuncts are also sometimes called circumstantial elements or circonstants.
}

(e.g., '“' I drank yesterday at school ${ }^{15}$ '). By contrast, adjuncts can be removed from the sentence without affecting its grammaticality (e.g., 'I drank milk.').

Since the 1980s, many theories of grammar have been built on the assumption that the syntactic realization of arguments is largely predictable from the meaning of their predicates. Such theories take many facets of the syntactic structure of a sentence to be projections of the lexical properties of its predicate and, in order to ensure this, they incorporate conditions requiring the arguments of the verb to be appropriately represented in the syntactic representation of its clause. Such principles include: the Principles and Parameters framework's Projection Principle (Chomsky, 1981, p. 29; Chomsky, 1986, p. 84); Lexical-Functional Grammar's Completeness and Coherence Conditions (Kaplan \& Bresnan, 1982, pp. 211-212); and Role and Reference Grammar's Completeness Constraint (van Valin, 1993, pp. 74-75; 2005, pp. 129-130; van Valin \& LaPolla, 1997, pp. 325326).

The Projection Principle is a stipulation proposed by Chomsky (1981, p. 29; 1986, p. 84) as part of the phrase structure component of the Principles and Parameters framework within the generativetransformational grammar. This principle requires that the subcategorization properties associated with lexical items be satisfied in all syntactic representations, so all the theta roles linked to all lexical heads must be realized by arguments.

The Completeness and Coherence Conditions proposed by Kaplan and Bresnan (1982, pp. 211-212) under the Lexical-Functional Grammar framework ensure that all the arguments of a predicate are present and that there are no additional arguments that the predicate does not require.

The Completeness Constraint is a principle formulated by van Valin and LaPolla (1997, p. 325) under the Role and Reference Grammar framework stating that all the arguments specified in the semantic representation of a sentence must be realized syntactically in the syntactic representation.

Consequently, in accordance with these three principles, apart from the subject, a ditransitive verb like 'give' requires two obligatory arguments, namely a direct object and an indirect object, which must appear in the sentence. The following subcategorization frame for the verb 'give' specifies its properties:

(8) give $(+\mathrm{V},-\mathrm{N})$, [ _ $\mathrm{NP} \mathrm{NP}]$ or [ _ $\left.\mathrm{NP} \mathrm{PP}_{\mathrm{to}}\right]$

It is out of this subcategorization frame that sentences like the following can be generated:

(9) English: a. Mary gave her sister a book.

\footnotetext{
${ }^{15}$ Context plays a major role in the distinction between arguments and adjuncts. This sentence would be grammatically correct if the verb 'drank' were understood in the sense of 'drank alcoholic beverages', which is not the case in this particular context.
} 
b. Mary gave a book to her sister.

Accordingly, in violation of the subcategorization frame of the verb, a sentence without one of the objects would be illformed ${ }^{16}$ :

(10) English: * Mary gave a book.

(11) English: * Mary gave (to) her sister.

In lexical argument languages ${ }^{17}$, such as English, German, Spanish or French, where full noun phrases are considered to be arguments of a predicate, it is not always easy to determine whether a clausal constituent is an argument or an adjunct simply by observing how a constituent behaves with respect to obligatoriness:

(12) English: My daughter writes (a letter) (to her boyfriend) (every week).

The omission of any of the two objects 'a letter' and 'to her boyfriend' or the adjunct 'every week' does not affect the grammaticality of the sentence. Rather, this strategy leads us to a further distinction between syntactic and semantic arguments.

On the one hand, we have the semantic valence of a predicate, which is a property that implies that we can infer how many arguments are involved in the event or state from the meaning of the predicate. On the other hand, we have the syntactic valence of a verb, which determines how many arguments the verb takes within a specific context. Although, as implied above, in theory semantics is assumed to determine syntactic structure, the number of syntactic arguments a verb can take is determined by the number of semantic arguments that the predicate expressed by the verb takes, it is not always possible simply to equate the number of semantic arguments with the number of syntactic arguments with which a verb appears. For example, although the verb 'write' is a three-place predicate requiring three semantic arguments, namely agent, theme, and recipient, it can also sometimes appear with just two syntactic arguments (e.g., 'My daughter writes (a letter) to her boyfriend.' or 'My daughter writes a letter (to her boyfriend).') or even none of them (e.g., 'My daughter writes (a letter) (to her boyfriend).'). In these examples, the semantic arguments of Theme ('a letter') and Recipient ('to her boyfriend') are left syntactically unexpressed but they are still part of the meaning of 'write', as it is still implicit that, firstly, there is something that a person wrote, and, secondly, there is a person to whom she wrote something. This implies that this predicate should still be considered a three-place argument predicate, although there may not be a syntactic constituent expressing any of the objects within the specific context. Finally, the adjunct in this sentence

\footnotetext{
${ }^{16}$ Standop (2000, p. 223) offers an example including the verb 'give' without one of its objects, namely, 'She gave a doll', which he considers to be acceptable. Context appears once again to be linked to this interpretation.

${ }^{17}$ See Pronominal Argument Hypothesis (Jelinek, 1984).
}

('every week') is optional in every interpretation.

This situation is indeed fairly common with regard to many transitive verbs (e.g., 'We ate (lunch) at home.', 'He sent (me) a letter.', 'They sold (us) a lot of books.', etc.): usually, you can, but need not, express some arguments syntactically because they are inferable from the context or because their specification is irrelevant to the context.

Unlike lexical argument languages, in pronominal argument languages such as Arapaho, Blackfoot, Cheyenne and Gros Ventre, it is generally agreed that the true arguments of the predicate are realized syntactically through pronominal clitics (i.e., pronominal arguments), while noun phrases behave like adjuncts:
(13) Cheyenne:
Náhe hetane é-véestomev-óho na-axaa'éhemo tỏhohko
DEIC man (3)-ask.for.DITR-3:4:I my.sister hammer
éšeēva.
yesterday
'That man asked my sister for a hammer yesterday.'

In this example, which includes the ditransitive verb véestomev 'ask for', the semantic arguments of Source and Theme are realized syntactically through a portmanteau pronominal clitic on the verb, namely -óho, indicating that a third person / proximate singular participant asks a fourth person/obviative singular participant for an inanimate singular object, and a full noun phrase (na-axaa'éhemo 'my sister' and tohohko 'hammer' respectively). As is obvious, the adjunct (éšeēva 'yesterday') is not cross-referenced on the verb.

The fact that only the pronominal clitics are in argument position in pronominal argument languages can be illustrated by the following example where only pronominal clitics resist omission without affecting the grammaticality of the sentence:
(14) Cheyenne:
Náhe hetane é-véestomev-óho.
DEIC man (3)-ask.for.DITR-3:4:I
'That man asked her for it.'

The expression of nominal arguments is not obligatory in Algonquian languages. As long as the referents are clear, speakers can simply mark participants on the verb with pronominal clitics. Speakers then have a number of choices in relation to the nominal arguments. They can leave them out entirely or mention any or all of them specifically. The choice of whether or not to use an explicit noun phrase is largely governed by pragmatic considerations involving saliency and emphasis.

As in argument marking in lexical argument languages, a noteworthy property of Algonquian languages is the significant role played by the referential factor of specificity. This feature plays a crucial role in their grammar as the specificity of the clause participants governs the alternation between 
intransitive, monotransitive and ditransitive stems in such a way that the reference of the participants must be specific for them to be cross-referenced on the verb:

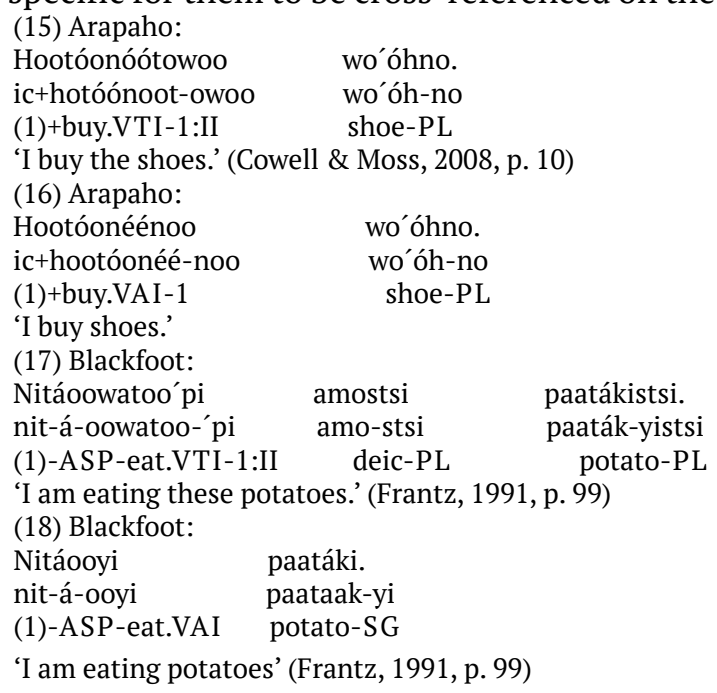

Despite the fact that the verb selects both an actor and a patient, only the actor is indexed on the verb in examples (16) and (18) because of the nonspecific referentiality of the patient. It is interesting that speakers can decide whether or not to mark a participant on the verb in the above examples. This decision implies the use of either an intransitive verb or a monotransitive verb, leading to a different form of the verbal stem. For example, while in (15) the participant wo'óhno 'shoes' is marked on the verb, in (16) the same participant is not, since the verb in this second case - namely, hootóonéé 'buy' - is an intransitive stem. In the first case, the monotransitive verb hotóónoot 'buy' includes a pronominal affix, that is -owoo, which indicates an action of a first person participant on an inanimate object. The first sentence is close to the English 'I buy the shoes', whereas the second sentence is closer to 'I buy shoes' or even 'I do shoe-shopping'.

In summary, examples of both lexical argument and pronominal argument languages point to the conclusion that a distinction between semantic transitivity and syntactic transitivity is crucial, which has less to do with the number of referents involved in the sentence, and much more to do with the relative saliency of a particular argument. The issue of saliency is central to Algonquian morphosyntax as, although most inflecting languages typically mark agents, patients and other fairly central participants on verb stems, Algonquian speakers are free to shift the valence of the stem and to choose the particular participant who or which will be marked on the stem owing to their pragmatic prominence or saliency, a complex pragmatic category involving the degree of definiteness, newness or contrastiveness of the referent and the general emphatic intention of the speaker. If an object is non-particular/non-specific in reference, it is elided in lexical argument languages and not marked on the verb of which it is the logical object in pronominal argument languages.

As regards the denomination of these objects, which appear to be non-obligatorily required by a predicate in a certain context, namely the absence of specificity, it seems plausible that calling them argument or adjunct is not entirely adequate because, on the one hand, although it is clear that they are semantic arguments of the predicate - the existence of the participants they refer to in the communicative event is implied as they are inherent to the intrinsic meaning of the predicate, which means that they are easily retrieved from the context - their presence is not essential to the interpretation of the sentence. Syntactically speaking (and morphologically speaking too in the case of pronominal argument languages), they are optional elements. Thus, it does not seem to be fair to treat 'a letter' and 'to her boyfriend' in (12), as with 'every week', as adjuncts simply because all these elements can be omitted without rendering the sentence ungrammatical. Neither does it seem adequate to consider paatáki 'potatoes' an argument in (18) in the same way as in (17) simply because the presence of a Patient is implied in the meaning of the predicate 'eat'. This appears to imply that the distinction between arguments and adjuncts is not clear-cut and that it may not be entirely correct to classify clausal constituents either as arguments or adjuncts. Perhaps, it would be better to classify arguments in a cline with obligatory arguments at one end, optional arguments, argument-adjuncts (Grimshaw, 1990), semi-core arguments (Arka, 2005) or derived arguments (Needham \& Toivonen, 2011) somewhere in the middle, and adjuncts or obliques at the other end. ${ }^{18}$

As mentioned above, the presence of a non-specific argument brings about a change in the syntactic valence of the verb, this being reduced by one. According to Frantz (1991, pp. 40-42), it might be appropriate to add the prefix "para-" to denominate a verb whose syntactic category in terms of transitivity has been modified. Thus, intransitive verbs, which may occur with a non-particular object, could be referred to as 'paratransitive' because they can occur with objects but do not agree with those objects. Likewise, as shown in Dryer (1986), some transitive verbs may occur with two syntactic objects, but the verb will show inflectional agreement with only one of them, which is commonly referred to as the "primary object". Such verbs could then be referred to as "paraditransitive" verbs because, although they are syntactically ditransitive (take two

\footnotetext{
${ }^{18}$ For a detailed account of the argument - adjunct distinction, see Needham and Toivonen (2011) and, for a finer-grained typology of adjuncts, see Rákosi (2006).
} 
objects), they are inflectionally (mono)transitive, since they show inflectional agreement with only the primary object. The other object, which is usually called the "secondary object", may be either particular or non-particular in reference.

Finally, if we take into consideration the importance of the verbal complex in pronominalargument (head-marking ${ }^{19}$ ) languages and bear in mind that the pronominal affixes on the verb are the core arguments of the clause and the independent referential phrases behave like adjuncts, the fact that a verb may not cross-reference all its obligatorily subcategorized arguments seems to question the validity of the assumption that all of the arguments explicitly specified in the semantic representation of a predicate must be realized syntactically within its core. This can be explained by arguing that there is a mismatch between semantic and syntactic transitivity caused by a semantic factor such as specificity, which limits the number of arguments marked in a verbal form, affecting the syntactic transitivity of the verb. On the other hand, this behaviour would confirm the widely held assumption that predicates present analogous semantic properties cross-linguistically, requiring the same number and type of semantic argument in every language. This is unlike the way in which these properties are syntactically represented, which may vary from language to language with the form in which they are realized syntactically different across languages.

The terms "word class" and "part of speech" are traditionally used to refer to a group of words showing similar grammatical properties so that words that are assigned to the same part of speech generally play similar roles within the grammatical structure of sentences and take a similar inflection because they possess similar properties.

The classification of words into different parts of speech can be found from the very beginning of the study of linguistics despite the lack of a definition of this term that provides unequivocal information regarding which grammatical properties should be taken into account in order to proceed with an accurate classification. One of the fundamental problems with the way traditional parts of speech are defined is that they are often an amalgam of semantic, morphological, and syntactic features, and the definitions are not usually reliable enough to be useful.

First, it is generally assumed that, in terms of the meaning or signification that they express: nouns are words denoting any abstract or concrete entity (e.g., person, place, thing, or idea); determiners delimit the reference of a noun in a given context; verbs denote

\footnotetext{
19 The name Pronominal Argument is now attached to a wide range of polysynthetic "head-marking languages" (Baker, 1996; Nichols, 1986).
}

actions or states of being; adjectives qualify nouns giving more information about the person or object signified; adverbs provide information about the manner, place, time, frequency, certainty, or other circumstances of the activity denoted by the verb; adpositions express a number of semantic relations (e.g., time, place, company, etc.); conjunctions connect or link words, phrases, clauses, or sentences, and interjections express feelings and emotions. Sometimes, it is not possible to use a semantic criterion on its own to identify the part of speech to which a word belongs owing to the existence of a great number of exceptions. For instance, 'revolution' and 'happiness' are nouns but denote an action and a state respectively.

Second, in languages with extensive inflection, morphology also helps to identify the part of speech to which a certain word belongs, as different word classes tend to carry distinct inflection in terms of gender, number, case, aspect, tense, mood, degree, etc. However, in other languages such as English, whose words are generally uninflected and the few inflective endings they show are mostly ambiguous, a correspondence between the form of a given word and the particular part of speech to which it belongs cannot be easily established. For example, in English '-ed' may mark a verbal past tense, a participle or a fully adjectival form; '-s' may mark a plural noun or a present-tense verb form; '-ing' may mark a participle, gerund, or pure adjective or noun. Although '-ly' is frequently an adverb marker, some adverbs (e.g., 'tomorrow, fast, very') do not end thus, while a number of words with that ending (e.g., 'friendly, ugly') are not adverbs.

Finally, the distribution of a given syntactic unit helps to determine the category to which it belongs. For example, it is assumed that nouns are normally accompanied by adjectives and determiners, pronouns are substitutes for nouns, verbs usually combine with adverbs, adpositions combine with nouns, and conjunctions connect clauses.

In English, commonly listed parts of speech ${ }^{20}$ are noun, verb, adjective, adverb, pronoun, preposition, conjunction, article or determiner, and sometimes particle and numeral. These categories are frequently used to describe many other languages, despite the fact that not all of them may have the same parts of speech. Algonquian languages, for instance, were always traditionally considered to have four major categories of speech: verbs, nouns, pronouns, and

\footnotetext{
${ }^{20}$ Many modern descriptions of grammar include not only lexical categories or word classes, but also phrasal categories, used to classify phrases, in the sense of groups of words that form units with specific grammatical functions. Phrasal categories may include noun phrases, verb phrases and so on. Lexical and phrasal categories together are called syntactic categories.
} 
particles $^{21}$ (Metallic, Cyr \& Sévigny, 2005, p. xii), most probably due to their morphosyntactic configuration.

In an attempt to delimit the different parts of speech in this group semantically, Algonquian languages could be assumed to possess the same categories as English with the exception of articles, which are absent. However, the morphological and syntactic properties of words in these languages can help us to identify the features some of these categories have in common so that a more accurate classification can be established.

Given their polysynthetic nature, the verb can be seen as the heart of the Algonquian languages. Many sentences consist only of a verb and many things that are expressed in English using separate words such as pronouns, adverbs, etc., occur within the verb in the form of affixes and clitics. Thus, the structure of the verb is extremely complex, as is illustrated in the following template showing the verbal structure of Cheyenne in the Independent Order:

It is generally assumed that the overall pattern of a verbal complex in any Algonquian language comprises a verb stem surrounded by inflectional suffixes. More specifically, in Plains Algonquian languages, the verbal complex may contain the following elements in the Independent Order. Leaving aside the clitics ${ }^{22}$ expressing evidentiality and illocutionary force, which can occur either at the left or the rightmost position ${ }^{23}$, the first position of the template is occupied by a verbal prefix signalling the most pragmatically salient participant. Secondly, in addition to this prefix, a number of particles commonly referred to as

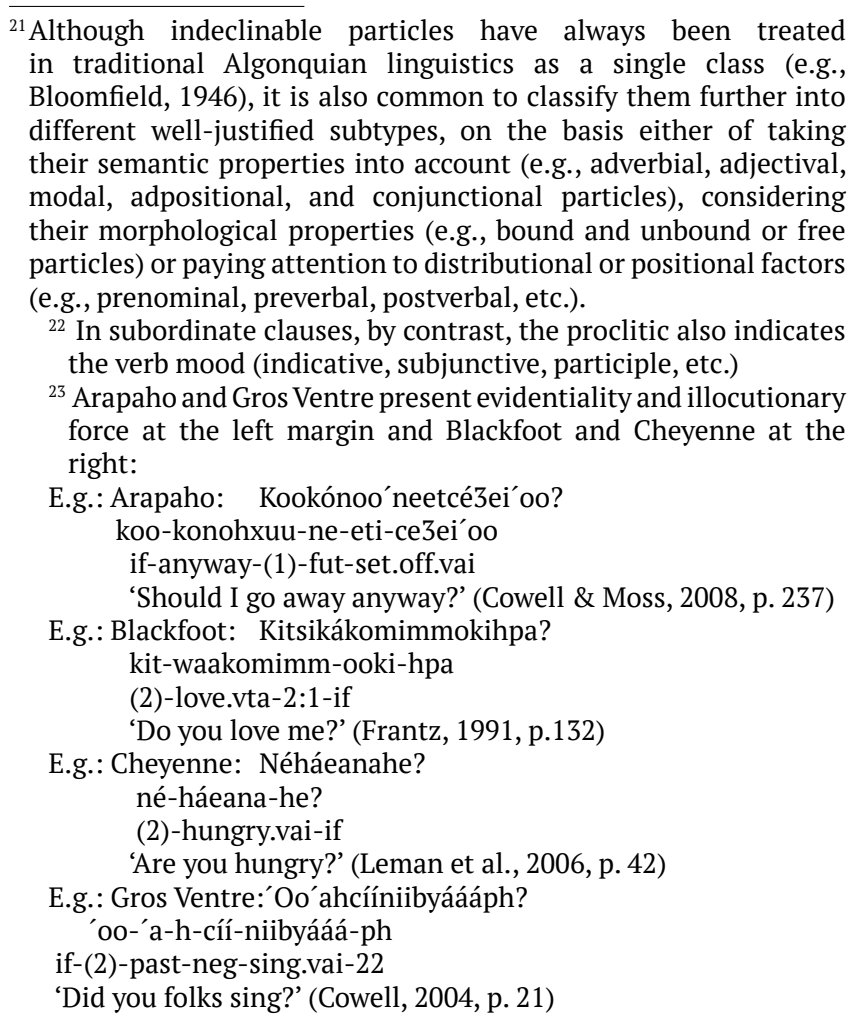

"preverbs" always come after the prefixes just listed and immediately precede the verb. There are two kinds of preverbal particles, grammatical and lexical preverbs, depending on the information they convey.

Grammatical preverbs express the distinction realis vs. irrealis, past or future tense, event quantification, negation, direction, and different types of aspect and modal specifications:

(19) Arapaho:

Heenéhnii3ooné3en 3ebiíhi'hínee hííze'.

ic+eti-neh-nii3óón-e3en 3ebiihi'hinee hii3e'

(1)+FUT-TRANSL-accompany.vta-1:2 to.there that over.there

'I will accompany you toward there.' (Cowell \& Moss, 2008, p. 93)

(20) Cheyenne:

Tse-nè-sáa'-évả-ho' e-anöheohtsé-he.

é+hte-nè-sáa'-évà-ho' e-anöheohtsé-he

(3)+FUT-ANAPH-NE G-back-arrive-down.i-go.FAI.3-NEG

'He won't come back down.' (Leman, 1980b, p. 179)

Lexical preverbs, by contrast, commonly indicate location, time and manner, and often correspond to the functions of English adverbs, auxiliary verbs and prepositions in meaning:

(21) Blackfoot:

Áíssáaka`po`takiwa.

Ø-á-ssáak-á po'taki-wa

(3)-ASP-try-work.VAI-3

'He's trying to work.' (Frantz, 1991, p. 89)

(22) Gros Ventre:

'íích'inonhóótowkúucaaach.

'îi-ch'i-non-hóótowkúucaaa-ch

ASP-NEG-fast-swallow.VAI-IF.2

'Don't swallow so fast!' (Cowell et al., 2004, p. 25)

As evidenced from these examples, the categories of clitics and preverbs can have multiple members simultaneously and, although they follow a relatively fixed order with respect to each other, this order may vary depending on the language in question.

Next, we have the most important element in the verbal complex, namely the predicate, which can be of a nominal or verbal nature in Plains Algonquian languages. Verbs are fully inflected words denoting states or actions and can occur in one of three possible orders: namely independent, conjunct or dependent and imperative, carrying inflectional morphemes providing grammatical information about the verbal mode, the direct/inverse distinction, the person, number, animacy, and obviation of the participants and the syntactic relations that hold between them.

As will be discussed in detail in the following section, which deals with multi-verb constructions, predicates in Cheyenne can either be simple or complex, depending on the number of identifiable morphemes of which they comprise:

$\begin{array}{llll}\text { (23) Arapaho: } & & & \\ \text { Nési } & \text { noh } & \text { híbetebihów } & \text { ceebíseení3i. } \\ \text { ne-si(h) } & \text { noh } & \text { i-betebihew-o } & \text { IC+ce'ísee-ni3i }\end{array}$


VERB STRUCTURE - INDEPENDENT ORDER

Prefix Preverb Predicate Pinal + Pronominal affix Postverb

Salience Irrealis Tense Direction (1) Event Quantification *Negation Direction (2) initial+medial+final Voice *Negation Cross-reference Evidentiality

Epis.Mod. Deon.Mod.

Aspect

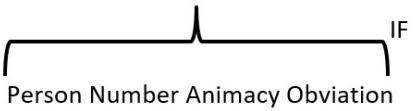

Person Number Animacy Obviation

Figure 1. Cheyenne verb structure in the independent order.

my-uncle and his-wife.obv (33)+walk.VAI-44

'My uncle and his wife are walking by.' (Cowell, 2008, p. 60)

(24) Blackfoot:

Anni otánoaawayi áóoyósiyináyi.

ann-yi w-itán-oaawa-yi Ø-á-ooyo'si-yini-áyi

DEIC-OBV their-daughter-OBV (3)-ASP-cook.VAI-4-D3P 24

'Their daughter cooks.' (Frantz, 1991, p. 65)

Examples (23) and (24) show instances of simple verbs, namely the intransitive animate verb ce'ísee 'walk' and ooyo'si 'cook', since they consist of a single stem, which cannot therefore be broken down into identifiable lexical elements. By contrast, the following examples illustrate examples of c o m plex predicates:

(25) Cheyenne:

a. Étoóomàše'še.

é-to-óom-àšéše

(3)-cool.i-liquid.M-drink.FAI.3

'He is drinking a cool liquid.' (Fisher et al., 2006, p. 230)

(26) Gros Ventre:

Nihto' 3onook'i.

IC+nih-to'-o3-on-ook'i

(3)+PAST-strike-by.foot-VTA-3:4

'He kicked him.' (Cowell et al., 2004, p. 55)

Both predicates, namely toóomàše'še 'drink a cool liquid' in (25) and to' 03 'strike by foot' in (26), are considered complex because they contain more than one lexical element: while the former consists of the adjectival morpheme to denoting the quality 'cool', a nominal morpheme óom meaning 'liquid', and the verbal morpheme àše'še expressing the concept of 'drink', the latter comprises a verbal morpheme to' conveying the idea of 'strike' and an adverbial morpheme 03 specifying that the action was carried out by using a specific part of the body, in this case the foot. These morphemes cannot constitute a word stem by themselves, so they should be considered to be stem-forming elements. For instance, àše'še 'drink' and $o 3$ 'by foot' should be considered shortened versions of verbal or nominal stems, rather than full stems.

\footnotetext{
24 -áyi- is referred to by Frantz (1991, p. 48) as the "distinct third person" pronoun, which serves to mark non-correferentiality between two third person participants in the same context, even though one of them may not be present in the same sentence (Frantz, 1991, p. 48)
}

A verbal stem may, therefore, vary its form because of the presence of other morphemes within the verbal complex, so that there might be a predicate consisting of up to three different stem-forming elements. According to traditional Algonquianist literature (Bloomfield, 1946; Goddard, 1979; 1996; Wolfart, 1973; among others), these verbal morphemes, which constitute a complex predicate, are initial, medial and final, in accordance with their relative position within the verbal complex, which can be said to have a tripartite stem structure (i.e., initial + medial + final).

Finally, following the verbal stem, Cheyenne also uses a myriad of suffixes covering the grammatical information of the obligatory participants of the event in terms of person, number, animacy, salience, direct or inverse direction and syntactic function. These suffixes serve to create the four classes of verb stems in terms of their transitivity and the animacy of their arguments.

(27) Gros Ventre:

Nihto'3onook'i.

ic +nih-to'-o3-on-ook'i

(3)+PAST-strike-by.foot-VTA-3:4

'He kicked him.' (Cowell et al., 2004, p. 55)

Nouns or substantives are inflected words denoting animate and inanimate referents that may accompany the verbal complex as separate forms in Algonquian sentences.

\section{(28) Arapaho:}

Neisónoo nihnoohówoot néíh'e hiníiteh'éího.

ne-isonoo(n) IC-nih-noohow-oot ne-ih'e(h) ini-iteh'eih-o my-father (3)-PAST-see.vta-3:4 my-son his-friend-OBV

'My father saw my son's friend.' (Cowell \& Moss, 2008, p. 64)

(29) Blackfoot:

Otsáápioyisi ksikksináttsiwáyi.

ot-iáápioyis-yi Ø-ksikksinattsi-wa-áyi

his-house-SG (3)-be.white.VAI-I-D3P

'His house is white.' (Frantz, 1991, p. 48)

These languages can present a number of uninflected words, traditionally referred to as particles, which can stand on their own in a sentence:

(30) Arapaho: Noh

neéeesnestóóbeen.

noh nee'eesi-nestoow-een

and thus-warn.VTA-11:2 
'And that is how we are warning you.' (Cowell \& Alonzo, p. 438): 31) Blackfoot:

Apinákosi áakaokska'so'pa.

apinákosi yáak-a-okska'si-o'pa

tomorrow FUT-ASP-run.VAI-12

'Tomorrow we will be running.' (Frantz, 1991, p. 33)

(32) Cheyenne:

Hóhkảse ná-me'-hóse-tó' nèšéve.

MODAL $^{25}$ (1)-should-again-do.something.vai.1

'What else could I do?' (Leman et al. 2006, p. 82)

(33) Gros Ventre:

'Î́-báátét-'o 'ikíhiinnóoo' 'îi'îííh bis'.

ic+'î́-bááté $\theta-{ }^{\prime} 0$ 'ikíhiinnóoo' 'ii'íííh bis'

(3)-asp-carve.vti-3:I spoon instr wood

'He is carving a spoon out of wood.' (Cowell et al., 2004, p. 15)

As we can see from these examples, these separate particles include parts of speech such as prepositions, adverbs, conjunctions or elements with modal content. However, this seems to be an exception as, unlike languages such as English or French, Algonquian languages do not appear to have separate forms to express person, qualities, quantity, instrument, direction, different aspectual and modal distinctions, verb tenses, etc. Rather, these languages also present a great number of uninflected particles that are usually affixed to nouns and verbs and cover a wide range of different parts of speech in other languages, such as quantifiers (34), adverbs (35), modals (36), numerals (27), conjunctions (38), and adpositions (39):

(34) Arapaho:

Bííshéi'nowúnee.

ic+beisií'hi-he' in-owunee

(2)+all-know.VTI-22:I

'You all know it.' (Cowell \& Moss, 2008, p. 207)

(35) Blackfoot:

Nitsikkínaiksiinoka.

nit-ikkina-Iksiin-o:kwa

(1)-gently-touch.VTA-3:1

'She touched me gently.' (Frantz, 1991, p. 92)

(36) Cheyenne:

Éme'évähóo'öhtseóo.

é-mé-évà-hóo'öhtse-o'o

(3)-should-back-go.home.VAI-33

'They should come back home.' (Leman et al., 2006, p. 99)

(37) Gros Ventre:

'Ahneh'inich.

'ah-neh'i-nich

CLM-be.three.VAI-44 (DUB)

'There were three of them, I guess.' (Cowell et al., 2004, p. 58)

(38) Arapaho:

[...] tohuunoohobéíno’ béénenéíi.

toh-1í-noohow-eino' IC+bene-nei'i

because-PAST-see.VTA-3:12 (12)+drink.VAI-12 (ITER $\left.{ }^{26}\right)$

'[...] because they see us drinking.' (Cowell \& Moss, 2008, p. 91)

${ }^{25}$ hóhkảse is a particle conveying an epistemic sense of
resignation.
(39) Blackfoot:

Amoma miistsísa áakitohkitopiiyináyi.

amo-ma miistsíS-wa yáak-it-ohkit-opii-yini-áyi

DEIC-STAT ${ }^{27}$ tree-OBV FUT-there-upon-sit.VAI-4-D3P

'He will sit on this tree.' (Frantz, 1991, p. 66)

Two lexical categories pose a challenge in terms of classification: adjectives, and pronouns. Firstly, adjectives share properties with verbs and particles:

(40) Arapaho:

Niih'oehit nihi'koohuut

ic+nih-hi3éíhi-t nihi'kóóhu-uton-i

(3)+very-be.good.VAI-3 run.VAI-PART-N

'He is very good at running.' (Cowell \& Moss, 2008, p. 111)

(41) Arapaho:

Nihcénenóúu nii'éíhiisóóno' nohúúxone'

ic+nih-cenen-o'u nii'eihii-soon-o' nohuuxon-e'

(1)+PAST-take.down.VTA-1:33 eagle-young.PL nest-LOC

'I took some eaglets down from their nest.' (Cowell \& Moss, 2008, p. 152)

(42) Arapaho:

Niikóoko3éínoo3ítoonéínoo.

nii-koon-ko3ein-oo3itoon-einoo

asp-redup-old-tell.story.vta-3:1

'He tells me old stories [on a regular basis].' (Cowell \& Moss, 2008, p. 202)

While in example (40) hi3éíhi 'good' functions as a non-verbal predicate, in examples (41) and (42) soon 'young' and ko3ein 'old' occur in the form of bound particles attached to the noun nii'eihii 'eagle' and the verb oo3itoon 'tell stories to' respectively.

Secondly, pronouns pose a serious problem in terms of categorization. Although Algonquian languages have a wide range of bound particles that function like most kinds of pronouns (e.g., personal, possessive, reflexive, reciprocal, etc.), there are a number of pronominal elements that appear to have different properties from those of verbs, nouns, and particles, reminding us of the existence of independent pronouns in Proto-Algonquian:

(43) Cheyenne:

Nénéehove nétavóomảtse tsé-to’se-véstoémòtse .

né-néehove né-ta-vóom-àtse tsé-to’se-véstoem-òtse

(2)-stand.be.VAI (2)-away-see.VTA-2:1 CLM-FUT-sit.with.VTA-2:3

nâ-htona

my-daughter

'You are the one (whom) I select (lit. see) to marry my daughter.'

(Leman, 1985, p. 21)

(44) Cheyenne:

Na'èstse vo'èstane éhvéehoo’o .

na'èstse vo'èstane é-h-vée-hoo'o

one someone (3)-PAST-camp.VAI (MED ${ }^{26}$ )

'A person was camping.' (Leman, 1985, p. 21)

On the one hand, the fact that the emphatic pronominal element nénéehove 'you' in (43) can stand

${ }^{26}$ The mediate mode is commonly used in the narration of legends
and folktales. 
on its own within the sentence may be due to the fact that it is an instance of a complex word that may be built like a copular construction. On the other hand, the indefinite element vo'éstane 'someone' could be considered as a noun, rather than an indefinite pronoun, since it can be accompanied by a numeral, as we can see from (44).

Perhaps, the most important challenge is provided by demonstrative pronouns, since, although they vary regarding gender (animacy), they represent two different degrees of distance (i.e., proximal and distal), and indicate two different types of reference (i.e., endophoric and exophoric). They do not inflect for obviation, cannot function as non-verbal predicates and usually cliticize to a following noun, which makes them lie halfway between nouns and particles:

\section{(45) Cheyenne:}

Námanèstóotāhonòtse hé tóhe mo'kèhanòtse.

ná-manèstóotāh-onòotse hé'tóhe mo'kèhanòtse.

(1)-make.for.ben.vta-1:3:II deic moccasin.pl

'I made these moccasins for him.' (Corral Esteban, 2014, p. 402)

(46) Cheyenne:

Hena'háanéhe hapó eveta tséohkèhešehósèstomónéto Hena'háanéhe hapó'eveta tsé-ohkè-heše-hósésta-omónéto deic likewise clm-usually-thus-tell.vta-x29:1

'That is likewise what was told to me...' (Leman, 1985, p. 37)

This may perhaps be accounted for by arguing that it is the reflection of the grammaticalization process whereby Proto-Algonquian independent pronouns have developed, firstly, into free particles and, finally, into bound particles or clitics. Furthermore, it could also account for the reason why pronouns have traditionally been cited as one of the four categories of Algonquian, as well as verbs, nouns, and particles.

This highlights the fact that parts of speech turn out to be, at best, fuzzy categories across languages, not identical or even present in every language, especially if we base their definition on morphological form or syntactic function. While there are universal tendencies, these do not seem to be absolute universal properties as the form/meaning connections differ across languages. Consequently, this variation in the number of categories and their identifying properties implies that separate analysis is required for each individual language.

Regarding the attempt at categorizing adjectives and pronouns in Plains Algonquian languages and bearing in mind their behaviour with respect to the criteria of morphological patterning and syntactic distribution, it is reasonable to classify adjectives as instances of bound particles, which can function as bound since they are attached to both nouns and verbs, in the latter case accompanying a sometimes covertly expressed copula. Likewise, it may be assumed that

\footnotetext{
${ }^{27}$ The symbol " $\mathrm{X}$ " is commonly used in Algonquian grammatical description to represent an unspecified agent.
}

pronouns should be treated as particles, although of two different kinds: firstly, those that can form verbal forms with the help of a usually covert copula should be regarded as bound particles, and, secondly, those, such as demonstratives, which accept some kind of morphological inflection but cannot function as nonverbal predicates, should be treated as free particles.

In summary, it is possible to observe a distinction between words in terms of their capacity to admit inflection. Thus, if we take into account this morphological criterion, two parts of speech can be obtained: firstly, declinable elements, to which a great range of inflectional morphemes can be attached, and, secondly, indeclinable elements, which will be referred to as particles and can be additionally divided into bound and free particles depending on whether they can stand on their own or not in a sentence. Depending on the type of grammatical information carried by this inflection, these declinable elements are classified in two different groups, namely verbs and nouns.

Furthermore, this attempt at categorization can be corroborated if we take into account the definition of the concept 'word'. After the introduction of the concept of 'Minimal Free Forms' by Bloomfield in 1926, words can be thought of as the smallest meaningful unit of speech that can stand by themselves, so they are traditionally defined as the smallest element that may be uttered in isolation with semantic or pragmatic content. Thus, the task of defining what constitutes a word involves determining where one word ends and another word begins, that is to say identifying word boundaries. In Plains Algonquian languages only verbs, nouns and particles can occur on their own within a sentence.

Consequently, the long list of word classes in English can be drastically simplified to only three in Plains Algonquian languages, as these languages make a tripartite distinction between nouns, verbs and particles, which can be both free and bound. The two universally valid categories, the verb and the noun, are also the two major categories, confirming the widely held assumption that all languages have at least nouns and verbs as word classes and that beyond these there are significant variations within different languages.

A different conclusion can, however, be reached if we take a different approach related to the complex relationship between syntax and morphology. The basic distinction behind these two terms lies in the fact that, while syntax deals with the phrase and sentence formation of words, morphology is related to word formation from morphemes. Although, at first glance, it would seem that what constitutes a sentence is clear, finding an exact definition for it becomes a much more complex task.

The sentence as a linguistic concept has been defined in many different ways, none of which is 
completely adequate. A traditional definition states that a sentence is a sequence of words delimited by orthography and pronunciation. A semantic definition says that a sentence is a group of words expressing a complete thought. A discourse-pragmatic definition includes a group of words expressing a topic (old information) and some comment (new information) about that topic., A more grammatical definition of the sentence states that, in terms of syntactic categories, a sentence contains a subject and a predicate.

In polysynthetic languages, such as the Plains Algonquian languages, a single word is usually delimited by a pause and can serve as a complete sentence much more frequently:

(47) Arapaho:

Heihoowní́zeyoohúútoné3.

IC-ihoowu-nii3i-eyoohuuton-e3e

(2)-NEG-INSTR-feel.VTA-1

'I am not preoccupied with you.' (Cowell \& Moss, 2008, p. 181)

(48) Blackfoot:

Nimáátakohkottahkayihpa.

nit-máát-yaak-ohkott-waahkayi-hpa

(1)-NEG-FUT-able-go.home.VAI-IF

'I can't go home.' (Frantz, 1991, p. 89)

(49)Cheyenne: Náohkėsáa’oné’seómepėhévetsėhésėsto’anéhe. ná-ohkè-sáa-'oné'seóme-pèhéve-tsëhésė-sto’ané-he

(1)-regularly-NEG-truly-well-Cheyenne-pronounce.VAI-NEG

'I truly don't pronounce Cheyenne very well.' (Fisher et al., 2006, p. 179)

(50) Gros Ventre:

'Oo'eeiciibahcciib'a'?

'oo-'eei-ciibahc-ciibé-'a

IF-(2)-ever-sweat.VAI-2

'Did you ever take a sweat?' (Cowell et al., 2004, p. 19)

Indeed, many sentences consist only of a verbal complex in both conversation and narrative, since nothing else is needed to make a sentence in these languages. Most of the syntactic information of the sentence is contained in the verbal complex, which could be considered to form a whole sentence since it includes a great number of morphemes expressing a myriad of both lexical and grammatical meanings (see Figure 1), with morphology rather than syntax expressing the distinction between subject and predicate. Thus, when it comes to accounting for word order, it may perhaps be more appropriate to consider word-syntax (i.e., taking a verb form as a sentence) rather than sentence-syntax. In this view, all morphemes would be taken as words, which would then be classified on the basis of their semantic content in different categories or parts of speech and, consequently, words like nii3i 'with' (47), ohkott 'able' (48), tsèhése ‘Cheyenne' (49), or 'eei 'ever' (50) could be considered an adposition, a modal verb, a noun, and an adverb respectively.

All this shows that there is no absolute division between syntax and morphology (and even phonology). The difficulty of completely separating morphology and syntax (and even phonology) is especially evident when comparing analytic languages like Chinese with polysynthetic languages like Eskimo: what in one language is a part of syntax will be a part of morphology in another. Given this range of complexity in terms of word formation, it stands to reason that the definition of 'word' cannot be uniform across languages. Hence, it is harder to maintain a uniform boundary between morphology and syntax and, thus, a uniform definition of syntax is also problematical.

This is indeed the most desirable analysis regarding the implications for the theory of Universal Grammar, since a similar number of categories could be established for all languages if we take into account the semantic content they express. In this view, a similar number of categories can be obtained by applying both morphosyntactic and semantic criteria, thus avoiding the mismatch resulting from the previous analysis. This assumption would therefore confirm the view that grammatical phenomena present similar semantic properties cross-linguistically.

\section{Stress, Pitch, and Tone}

Plains Algonquian languages, including Arapaho, Blackfoot, Cheyenne and Gros Ventre, demonstrate significant phonological differences when compared to other Algonquian languages (Goddard, 1994, 1996, and 2001; Campbell, 1997; Mithun, 1999). This section will show that these languages represent a challenge in terms of analyzing their prosodic systems and, thus, finding an accurate term to describe the pattern they exhibit. The problem lies in the characterization of the major exponent of prominence in these languages, which has variously been referred to in the literature as stress, pitch or tone. Although languages like Arapaho (Goddard, 1974 and 2001; Pentland, 2006; Salzmann, 1963 and 1983; Cowell \& Moss, 2008), Blackfoot (Frantz, 1997; Frantz and Russell, 1995; Kaneko, 1999; van Der Mark, 2001 and 2003), Cheyenne (Frantz, 1972a and 1972b; Leman, 1980a and 1981), and Gros Ventre (Goddard, 1974; Taylor, 1994; Pentland, 2006) are commonly referred to as pitch-accent languages, more recent studies have defied this analysis by claiming that: Arapaho could have a stress system (Fountain, 2016) or a tone system (Mithun, 1999); Blackfoot could have a stress system (Frantz, 1971; Taylor, 196928; Uhlenbeck, 1978) or a tone system (Stacy, 2004); and Cheyenne could have a stress system (Frantz, 1952a;

${ }^{28}$ Taylor (1969) states that Blackfoot is a stress language, where pitch and stress happen to fall at the same place in the word. His analysis, therefore, proposes a split system where both stress and pitch are found within the same word depending on a given context. 
Leman \& Rhodes, 1978) or could be developing a tone system (Leman, 1981; Milliken, 1983; Mithun, 1999).

Prominence is a linguistic term used in phonetics and phonology to refer to the relative intonational emphasis placed on a certain syllable in a word or a certain word in a phrase, clause or sentence. It is typically signaled by properties such as increased loudness, longer articulation of a vowel, different articulation of a vowel, and changes in pitch depending on the language, which lead to particular types of accent ${ }^{29}$ : namely a stress accent in the case of loudness, a quantitative accent in the case of length, a qualitative accent in the case of differences in articulation, or a pitch accent and tone in the case of pitch (van der Hulst, 2010, pp. 13-48).

Along with extensive vowel devoicing, the presence of pitch variation is the most salient prosodic aspect of the phonological systems of the Plains Algonquian languages, so this seems to be sufficient to exclude the possibility that these languages have a stress system at the same time as making it clear that there should be no objection to referring to these languages either as pitch-accent languages or tone languages. The problem is, however, that there is a great deal of controversy concerning the demarcation between the terms stress, pitch and tone, especially regarding the definition of the term "pitch accent" (Hyman, 2006 and 2009; Salmons, 1992).

Firstly, Hyman (2009) formulates two necessary properties of stress, namely culminativity (i.e., that only one syllable can be stressed or accented) and obligatoriness (i.e., that, additionally, each word must be stressed at least once). Secondly, pitch is a perceptual property of sounds involving judgment as to whether a sound is high or low in the sense associated with musical melodies and, while all languages use pitch features for intonational purposes ${ }^{30}$, in pitch accent languages they are a property of words. Finally, tonal languages use variations in pitch or tone to distinguish units (phonemes, syllables, words). Although there is still considerable debate concerning the difference between a system with pitch accent and one with tone, the basic premise appears to be, as Hyman (1975, p. 231) has suggested, that while a tonal language has a tone on every syllable, a pitch accent language has only one tone per word, making it similar to stress in languages like English.

However, tonal systems also appear to show

\footnotetext{
${ }^{29}$ The term "accent" has been traditionally used in many different ways and applied to a wide range of phonological phenomena. Throughout this section I will use the term "accent" to refer to the type of prominence observed in every system (e.g., stress accent or pitch accent).

${ }^{30}$ Intonation(al) languages use variations of pitch to describe intonation, such as methods of conveying surprise, changing a statement into a question, or expressing information flow (i.e., topic-focus distinction).
}

restrictions, mostly resulting from tonal spreading or assimilation (Hyman, 2007), from using a limited set of tonal melodies which are properties of morphemes rather than of syllables (Leben, 1971; Goldsmith, 1976b; Halle \& Vergnaud, 1982), from the avoidance of sequences of identical tones, or indeed from relations between tone distribution and stress. Thus, most researchers tend to assume that there is no reason to limit the term tonal language to cases in which the distribution of tones is entirely unrestricted. ${ }^{31}$

In an attempt to mark the distinction between pitch accent with respect to stress and tone, Bybee et al.'s (1998, p. 277) definition of the term states that pitch accent languages have pitch as the primary indication of accent and show constraints in terms of the pitch patterns of words (e.g., the number of pitch contrasts (high vs. low) in the number of tonic syllables or morae in a word, etc.). Consequently, they may have a more complex accentual system than stress-accented languages - in some cases they may even have more than a binary distinction - but are less complex than fully tonal languages, which assign a separate tone to each syllable or mora.

The consideration of pitch accent as a type of accentual or tonal system is, to say the least, unclear, as illustrated by Hyman (2001, 2006, 2009), who treats stress systems and tone systems as prototypes. According to Hyman (2009, p. 219), "pitch accent" is a label for a large class of hybrid systems that mix stress and tonal properties in various ways, or systems that are clearly tonal, although they display various restrictions in terms of the distribution of tones.

In summary, while prosodic systems are typically divided into three types, namely tone, stress and pitch accent in contemporary analysis, there is a grave inconsistency throughout linguistic literature with respect to the terminology used to describe them: more particularly when analyzing pitch accent systems, which provide the majority of inconsistencies with respect to the nomenclature ensuing from this abundant terminological confusion. What is striking is that, despite the lack of clarity as to whether pitchaccent languages present distinctive properties allowing them to be differentiated from both stress accent and tone systems, a great number of languages worldwide continue to be commonly referred to as pitch-accent languages. In an attempt to eliminate this inconsistency and taking Stacy's (2004) study on Blackfoot as a model, I will analyze the prosodic systems in Plains Algonquian languages in terms of

\footnotetext{
${ }^{31}$ Tonal languages can be ranked on a scale of tonal density (Gussenhoven, 2004), which indicates how many word positions (syntagmatic dimension: the number of positions displaying by tonal restrictions) have how much tonal contrast (paradigmatic dimension: the number of contrastive options per position). Such a scale indicates the relative functional load of tone properties.
} 
the properties characterizing stress accent and tone systems, which do appear to be very clearly delimited.

\section{Nature of Prominence}

According to van der Hulst \& Smith $(1988$, p. 4), if the acoustic features of prominence correlate with pitch alone, the system is tonal, whereas if acoustic features include pitch, duration, intensity and so forth, it is a stress accent system.

The examination of the properties shown by accent in Plains Algonquian languages provides strong evidence that accent is realized acoustically by pitch rather than by intensity or duration.

\section{Distribution: Culminativity, Adjacency, and Obligatoriness}

Culminativity is claimed to be a principle characteristic of stress systems (Hyman, 1977; Beckman, 1984; van der Hulst \& Smith, 1988; van der Hulst, 1999; among others), where it plays a central role, ensuring that there is one, and only one, prominence within the accentual unit, which can range from a word to a phrase, as well as of pitch accent systems (Beckman, 1986; van der Hulst \& Smith, 1988; van der Hulst, 1999, among others), but never of tonal systems, which show a free distribution of accent, as multiple adjacent tones are acceptable:

(51) Arapaho:
nenítee
'person'
(52) Blackfoot:
nínaa
'man'

(53) Cheyenne:

éškeme

'grandmother'

(54) Gros Ventre:

'áas'i

'husband'

Despite evidence presented above supporting the claim of culminativity, this most important characteristic of stress accent and pitch accent systems is very frequently contravened. Although the formation of compounds (nominal or verbal complexes) is the most likely environment in which to find multiple pitch accents, simplex (not compound) words also provide a number of examples including more than one pitch per accentual unit:
(55) Arapaho:
wóoxé
'knife'
(56) Blackfoot: máttsiiíítaa 'bat'

\author{
(57) Cheyenne: \\ kàsóhéso \\ 'boy' \\ (58) Gros Ventre: \\ ní́haanéhi \\ 'own'
}

These examples contain multiple pitch accents for instance, and consultations with native speakers would suggest they are not complex. Thus, in conclusion, many words in Plains Algonquian languages appear to have more than one prominent peak, which makes these languages look tonal, at least when seen from a restricted perspective.

Further to this property, a second example of culminativity violation is concerned with the placement of adjacent pitch accent within the domain:

(59) Arapaho:

hoséíno'

'meat'

(60) Blackfoot:

áíksini

'pig'

(61) Cheyenne:

háóéná

'pray'

(62) Gros Ventre:

'otóóúh

'will'

Instances of adjacent prominence peaks seem to be found in a wide range of contexts, indicating that there is apparently no strategy to avoid them within the word and therefore illustrating the fact that culminativity is often flouted in these languages. ${ }^{32}$ Finally, it is also of note that Plains Algonquian languages have words with apparently no pitch accent at all, which means a

\footnotetext{
${ }^{32}$ It is possible to find examples in Plains Algonquian languages that appear to indicate that they do not usually tolerate adjacent pitchaccented syllables in compound words:

E.g.: Arapaho: héébetóóku eebét-óóku big-rabbit 'kangaroo' (Cowell \& Moss, 2008, p. 29)

E.g.: Blackfoot: káta'yáak kátá'-áák neg-fut (Stacy, 2004, p. 130)

E.g.: Cheyenne: hetanénahkohe hetané-náhkohe male-bear 'male bear'

E.g.: Gros Ventre: ákisiibáa 'akisí-báa small-nose 'small nose'

These examples could show that these languages are, to a certain extent at least, metrical in nature, since the accents can be redistributed by word-level accent rules or strategies (accent shift or accent displacement) in order to avoid adjacent syllables. However, these are instances of local dissimilation rather than pitch accent deletion rules, as more tones are present throughout the rest of the word.
} 
violation of obligatoriness in stress accent and pitch accent theory:

(63) Arapaho:

betooot

'dance'

(64) Blackfoot:

isttsipatakkayayi

'run'

(65) Cheyenne:

hetane

'person'

(66) Gros Ventre:

biit'oh'o

'moccasin'

\section{Function of Prominence}

Following Trubetzkoy's (1939)'s typology of functions of phonic substance, I will analyze Plains Algonquian languages in terms of their behaviour with respect to the distinctive or descriptive, contrastive or culminative, and delimitative or demarcative functions that are commonly attributed to pitch. Firstly, the distinctive function lies in the ability of pitch accent to distinguish lexical units, making it paradigmatic by nature, which is typical of tonal languages, but not of stress-accent systems. ${ }^{33}$ This means that more minimal pairs should be found in tonal systems than in any other type of system, because the primary function of tone is to differentiate items (syllables, for instance), as opposed to organizing a word or phrase hierarchically, which is typical of stress and pitch accent. Secondly, the contrastive function serves to differentiate between items, so it is related to the analysis of the distinctive properties that some phonological elements show with respect to others within the same lexical unit. Finally, the delimitative function - a special kind of contrastive function would involve marking the boundary between lexical units. As we can see, the contrastive and delimitative functions are syntagmatic and are ultimately derived from the culminative function, since each unit is intended to carry one pitch accent and no more, and thus an expected property of non-tonal languages.

As an instance of distinctive function, tone languages use contrasting pitch in much the same way that vowels contrast. In other words, when all other phonemic information is identical, changing the pitch in a word or syllable changes the core meaning of that word. It is possible to find words in Plains Algonquian languages that can be distinguished based on pitch alone:

\footnotetext{
33 According to Beckman (1984), stress can also distinguish between lexical units, but the contrast among more prominent and less prominent portions of a phrase is a far more important function of stress.
}

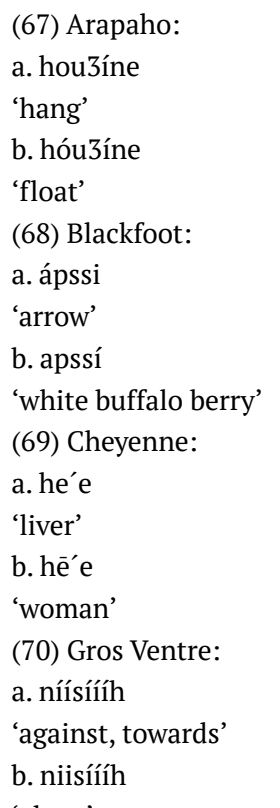

'alone'

While tonal contrasts are distinctive in these languages, minimal pairs such as those listed above are rare, maybe due to their polysynthetic nature. Thus, although a few cases of minimal pairs can be found, this function is unsatisfactorily represented in the data, so it is not unreasonable to conclude that Plains Algonquian languages do not do justice to the distinctive function, at least not to the same extent as in other tonal languages, such as Chinese, where the existence of minimal pairs is extremely common.

Example (51-54) illustrates the contrastive function in Plains Algonquian languages, since it shows a word containing only one pitch accent. However, as we can see from examples (55-58), (59-62), and (63-66), this function is not very relevant in these languages as they show instances of multiple occurrence, adjacency, and the absence of prominence peaks, all of them violations of the properties of culminativity and obligatoriness, which are typically associated with stress-accent languages and, by extension, pitchaccent systems too.

A further property that is traditionally attributed to stress-accent and pitch accent languages is the presence of alignment or edge-effects, which enable the pitch accent to signal the boundary between lexical units, thereby illustrating the delimitative or demarcative function. According to Hymen (1977a, p. 41), the closer to the edge the pitch accent falls, the more the pitch accent fulfills this function. The following examples confirm the presence of edgeeffects in these languages, showing both left alignment (a) and right alignment (b):
(71) Arapaho:
a. bétee
'(be) holy'
b. niicíi 
'river'

(72) Blackfoot:

a. áápotskina

'cow'

b. mohsokó

'road'

(73) Cheyenne:

a. éškeme

'grandmother'

b. hoo'kohó

'rain'

(74) Gros Ventre:

a. níhooyoo

'(be) yellow'

b. kookóh

'just'

Examples (71-74) indicate that edge-effects are obeyed, supporting the assumption that Plains Algonquian languages make use of the delimitative function. However, data throughout this research demonstrate that edge-effects in these languages are not strong enough to suggest a clear evidence of a right- or left-headed tendency, implying that, although the delimitative function is sometimes respected, it is not a rule in these languages. Besides the fact that it is very common for a word in Plains Algonquian languages to have more than one prominent peak (5558), words apparently show no restrictions as to where the pitch accent can fall:

(75) Arapaho:
tecénoo
'door'
(76) Blackfoot:
paapó'sin
'lightning'
(77) Cheyenne:
mo'éhno'ha
'horse'
(78) Gros Ventre:
titékin
'roll'

These examples illustrate the absence of restrictions regarding the position upon which the pitch accent can fall, so it would seem that any accent-bearing unit can be accented in these languages. In conclusion, the inconsistent nature of alignment provides evidence more consistent with a tonal, than a stress-accentual, proposal for Plains Algonquian languages.

In summary, on the one hand, minimal pairs may occur in Plains Algonquian languages although such pairs are so rare that this is not enough to claim that the distinctive function is engaged, as would be expected of tonal languages. On the other hand, the fact that words containing multiple pitch accents are very common in these languages would seem to show - along with the assumption that edge-effects are not active most of the time - that the contrastive and delimitative functions are not fully obeyed either, as would be the case in stress-accent systems. Thus, the examination of the function that prominence has in these languages does not provide conclusive results as to whether they show properties consistent with a stress-accent or a tonal analysis. Perhaps it could even be argued that, if prominence in these languages is not needed to distinguish between lexical items, then the use of pitch as a contrastive device would also appear to be superfluous, thus giving prominence an organizational function - possibly supported by the widespread violations of culminativity and a slightly higher tendency for pitch to be left-aligned - that would point to a syntagmatic relationship between tone and stress. Stress would, then, result from the imposition of a form of metrical structure, leading us to consider Plains Algonquian pitch patterns as hybrid systems showing properties of both stress-accent and tonal languages.

\section{Metrical Structure}

Following Lahiri (2001, p. 1347), metricality - that is, the ability of stress systems to organize stress patterns hierarchically - is a second fundamental property of stress systems. Working in tandem with culminativity, this property creates one prominence per accentual unit by relegating any stress besides the primary one to a secondary position so that different levels of prosody are parsed hierarchically. Thus, once feet are built, stress assignment occurs, falling on the head of certain feet. Seen in this light, both pitch accent and, especially, stress function metrically, where syllable weight and culminativity dominate and minimal prominence is present at word level, with maximal prominence occurring at phrasal level. By contrast, pure tonal systems lack metrical properties so that the position of the accent is generally unaffected by syllable weight. Tone is, thus, a lexically specified feature, meaning that it is unpredictable, that is to say, there is no way of predicting the placement of pitch.

As aforementioned, Plains Algonquian languages have pitch as the major acoustic correlate of prominence, making them, in this respect, similar to tone languages, rather than stress accent languages. Pitch accent is a morpheme-level phenomenon, as it is part of the underlying form of the morpheme. However, despite being lexically specified for every morpheme, pitch accent is also affected by syllable structure, since, when these morphemes are combined in phonological words, predictable, word-level pitch accent rules cause the redistribution of the pitch accents within the word:

(79) Arapaho:

heebe3iiséi 
heebe3ííhii-hísei

immense-woman

'big woman'

(80) Blackfoot:

ómahkomitaa

ómahk-imitáá

big-dog

'big dog'

(81) Cheyenne:

hesta'séve'ho'e

hésta'se-vé'ho'e

snow-whiteman

'Santa Claus'

(82) Gros Ventre:

'akisiníícááh

'akisí-niicaah

little-river

'Milk River'

There are numerous examples where the accent of a phonological word does not seem to be a fixed lexical property of the stem itself. Rather, it may change depending on the affixes with which it combines.

Thus, it would seem that, although there is no clear evidence that words in these languages are able to build feet, pitch accent processes appear to interact with syllable structure and surface phonology quite significantly, so they could be said to have a mixed pitch pattern system as they exhibit properties of both stress-accent and tone systems in terms of metrical structure.

\section{Syllable Weight}

Unlike Cheyenne, where the Proto-Algonquian distinction between long and short vowels gave rise to a distinction between high and low pitch, in Blackfoot, Arapaho and Gros Ventre vowels can occur in two contrastive lengths, that is, either short or long. ${ }^{34}$ These languages show many instances of words that reflect a correspondence between prominence assignment and the presence of a long vowel:

(83) Arapaho:

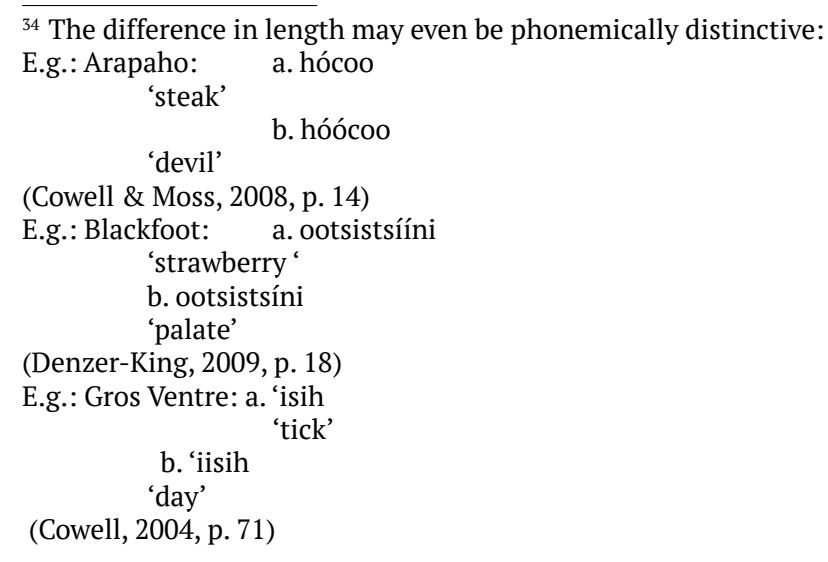

híísi

'day'

(84) Blackfoot:

míín

'berry'

(85) Gros Ventre:

cíiw'u

'canoe'

However, there are a lot of examples that show a clear lack of quantity-sensitivity, as prominence can also fall on a short vowel:

(86) Arapaho:
bénes
'arm'
(87) Blackfoot:
makóyi
'wolf'

(88) Gros Ventre:

báh

'friend'

Consequently, the data presented in this section cannot substantiate the claim that syllable weight is an integral element in the assignment of pitch in Blackfoot, Arapaho and Gros Ventre, because although heavy syllables appear to attract prominence, it can also fall on both short and long vowels, proving that syllable weight - a feature of stress assignment appears to interact rather inconsistently with pitch in these languages.

\section{Prototypical Realization of Prominence}

It is generally assumed that in tonal systems the tone-bearing unit is prototypically the syllabic segment (e.g., mora or vowel), whereas in stress systems the stress-bearing unit is the syllable. Pitchaccent languages tend to give more prominence to the phonological phrase, rather than the word, as the accent-bearing unit.

The morphemes in Plains Algonquian languages all seem to have an underlying pitch accent marked by a high tone, although this may become affected by surface prosody rules functioning at word level.

\section{Reciprocal Influence of Prominence on Phonology}

While the effect of prominence on phonology in tonal languages can be considered self-contained (i.e., tones affect tones but not consonants or vowels), in stress languages the effect is non-contained as consonants and vowels can be affected by stress (i.e., consonants can be strengthened or weakened under stresslessness, stressed vowels can be lengthened/ diphthongized, and unstressed vowels can become peripheral). Regarding Plains Algonquian languages, it seems that prominence does not affect the quality 
of consonants and vowels, which implies that, in this respect, they can behave like tonal systems.

Likewise, while in stress systems stress is affected by syllable weight, in tonal languages tone may be affected by factors like the type of consonant, voice quality, glottal stop, etc., with an important role to play in tone genesis and evolution. As regards the presence of this influence in Plains Algonquian languages, it seems that some tonal processes - local dissimilation, glottalization and accent spread, for instance - appear to play an important role in the formation of tone..$^{35}$

A summary of the results obtained through the analysis of the phonetic properties of the prosodic systems in Plains Algonquian languages is included in Table 1. In keeping with Hyman's (2001, 2006 and 2009) proposal concerning prototypes, and van der Hulst \& Smith's (1988) and Yip's (2002) concept of continuum, I understand that there are only two categories - stress and tone - which exist on a continuum where there are pure tone systems [+tone] at one end and pure stress systems [+stress] on the other. There may also be other languages whose prosodic systems fall anywhere along these axes, depending on how prototypical the prosodic features of that language are, which places pitch accent systems somewhere between the two ends.

The evidence given in this table shows a higher number of correlations with tonal phonology, which, together with the fact that several obvious tonal processes such as glottalization, accent spread and tone dissimilation can be observed in these Native American languages, may indicate that they fit more readily into the category of tone languages than stress-accent languages.

Although phonetic investigations confirm that in Plains Algonquian languages pitch is the key correlate of prominence and that, consequently, the prosodic systems of these languages are typically identified as pitch accent systems, they consistently contravene characteristic pitch accent principles, including gross violations of obligatoriness (at least one prominence per word), culminativity (at most one prominence per

\footnotetext{
35 Besides the persistent violation of culminativity and obligatoriness, other strong arguments can be cited in support of the view that Plains Algonquian languages represent transitional systems from stress-accent to tone. These arguments are illustrated by instances of tonal processes such as glottalization and accent spread, two processes typically found in tonal languages:

E.g.: Arapaho: néé eesííni

nééeesi-íni

thus-deriv

'It is thus.' (Cowell \& Moss, 2008, p. 29)

E.g.: Blackfoot: ómaxkapì:si

ómahkapi'sii

‘timber wolves’ (Stacy, 2004, p. 119)

The correspondence between glottalization and tonogenesis, along with the presence of accent spread, lend growing support to the hypothesis that Plains Algonquian languages would be better viewed as tone-like languages.
}

word) - maybe the strongest arguments pointing to a tonal system -, and the lack of clear and consistent edge-effects.

In conclusion, the behaviour shown by the prosodic system of Plains Algonquian languages with respect to the phonetic criteria under examination would point to their being considered as hybrid systems, which share properties with both stress accent and tonal systems. Although in Hyman's theory the middle region is typically understood to be where pitch accent systems fall, the use of the label "pitch accent" for these prosodic systems cannot be regarded as entirely accurate owing to the lack of standards against which to measure what actually constitutes pitch accent. In fact, it might even be inappropriate to attempt to do so given the enormous variety found in each pitch accent system ${ }^{36}$, which makes phonetic analyses of this kind of system both inconsistent and problematic. It might be better to use a denomination such as "transitional" to identify this type of hybrid system since it makes it clear that the prosodic system in question shares the properties of both stress and tone systems, thus avoiding the temptation to view it as a subset of either stress or tone systems ${ }^{37}$, and allowing us to classify it more freely as more stress-like or tone-like depending on the phonetic analysis of its prosodic features. This could be of significant benefit since we do not then need an accurate definition of a term with distinctive properties, with the language in question being referred to as a pitch accent language having a system that differs from both a stress accent and a tonal system.

In conclusion, if we take into account the fact that the key correlate of prominence in the ProtoAlgonquian ${ }^{38}$ prosodic system was stress at the same

\footnotetext{
${ }^{36}$ On the one hand, Yip (2002, p. 260) states that pitch-accent languages, "occupy transitional ground between "pure" tone and "pure" stress languages, and that pitch-accent is simply "a convenient descriptive term for a particular type of language in which tone is used in a rather limited way, with one (or perhaps two) tone melodies". On the other hand, Hyman (2009, p. 219) claims that no language should be analyzed with pitch-accent, as languages in the middle of the continuum present indeterminate properties and, consequently, are not a coherent class. Finally, Clark (1988, pp. 51-53) suggests that under the traditional definition of pitch-accent, two types of systems can be interpreted: 1) a restricted tone language which has just one lexical melody or 2) a metrical language in which accent is realized as a high tone.

37 Basically, the culminative nature of pitch accent, claimed to be a core characteristic of stress and pitch accent systems but never of tonal systems, prompted its subclassification under stress systems (cf. Prague School linguistics, including Jakobson, 1931; Trubetzkoy, 1939; among others), while the use of pitch by pitch accent systems prompted its subclassification under tone systems (Gandour, 1978; Beckman, 1986; van der Hulst \& Smith, 1988; Yip, 2002 , etc.).

${ }^{38}$ As in English, German, Spanish or French, Proto-Algonquian had a stress system, whereby stress was predictable, since long vowels and every second vowel received a stress. A stress accent system persists in Algonquian languages like Plains Cree, Menominee, Montagnais or Ojibwe but this does not seem to be the case in the
} 
Table 1

Summary of the phonetic properties of the prosodic systems in Plains Algonquian languages

\begin{tabular}{|c|c|c|c|c|}
\hline Criterion / Language & Arapaho & Blackfoot & Cheyenne & Gros Ventre \\
\hline Correlate of prominence & Pitch: [+tone] & Pitch: [+tone] & Pitch: [+tone] & Pitch: [+tone] \\
\hline \multirow[t]{3}{*}{ Distribution } & $\begin{array}{l}\text { - Violation of } \\
\text { culminativity: [+tone] }\end{array}$ & $\begin{array}{l}\text { - Violation of } \\
\text { culminativity: [+tone] }\end{array}$ & $\begin{array}{l}\text { - Violation of } \\
\text { culminativity: [+tone] }\end{array}$ & $\begin{array}{l}\text { - Violation of } \\
\text { culminativity: [+tone] }\end{array}$ \\
\hline & - Adjacency: [+tone] & - Adjacency: [+tone] & - Adjacency: [+tone] & - Adjacency: [+tone] \\
\hline & $\begin{array}{l}\text { - Violation of } \\
\text { obligatoriness: [+tone] }\end{array}$ & $\begin{array}{l}\text { - Violation of } \\
\text { obligatoriness: [+tone] }\end{array}$ & $\begin{array}{l}\text { - Violation of } \\
\text { obligatoriness: [+tone] }\end{array}$ & $\begin{array}{l}\text { - Violation of } \\
\text { obligatoriness: [+tone] }\end{array}$ \\
\hline \multirow[t]{3}{*}{ Function } & - - distinctive: [+stress] & - - distinctive: [+stress] & - - distinctive: [+stress] & - - distinctive: [+stress] \\
\hline & • - contrastive: [+tone] & • - contrastive: [+tone] & • - contrastive: [+tone] & - - contrastive: [+tone] \\
\hline & - - delimitative: [+tone] & •- delimitative: [+tone] & - - delimitative: [+tone] & - - delimitative: [+tone] \\
\hline Metrical structure & Probably [mixed] & Probably [mixed] & Probably [mixed] & Probably [mixed] \\
\hline $\begin{array}{l}\text { Presence of toneless } \\
\text { words }\end{array}$ & Yes [+tonal] & Yes [+tonal] & Yes [+tonal] & Yes [+tonal] \\
\hline Syllable weight & No [+tonal] & No [+tonal] & Yes [+stress] & No [+tonal] \\
\hline $\begin{array}{l}\text { Realization of } \\
\text { prominence }\end{array}$ & $\begin{array}{l}\text { Morpheme }=\mathrm{TBU} \\
{[+ \text { tonal }]}\end{array}$ & $\begin{array}{l}\text { Morpheme }=\text { TBU } \\
{[+ \text { tonal }]}\end{array}$ & $\begin{array}{l}\text { Morpheme }=\mathrm{TBU} \\
{[+ \text { tonal }]}\end{array}$ & $\begin{array}{l}\text { Morpheme }=\text { TBU } \\
{[+ \text { tonal }]}\end{array}$ \\
\hline $\begin{array}{l}\text { Effect of prominence on } \\
\text { phonology }\end{array}$ & Improbable [+tonal] & Improbable [+tonal] & Improbable [+tonal] & Improbable [+tonal] \\
\hline $\begin{array}{l}\text { Effect of phonology on } \\
\text { prominence }\end{array}$ & Yes [+tonal] & Yes [+tonal] & Probable [+tonal] & Probable [+tonal] \\
\hline
\end{tabular}

time as the findings obtained in this analysis, it could be argued that the analysis of the prosodic system of Plains Algonquian languages reflects a transition from a stress accent system in Proto Algonquian to a tonal system and that, as the present state of the evolution lies midway between the two, the system could be more appropriately referred to as transitional. Furthermore, if we reappraise Plains Algonquian languages from the point of view of their emerging tonal systems, seeing them as languages in transition towards becoming tone languages, we would also possess a much more cohesive description of the languages' prominence system since they are geographically located in the vicinity of a number of other languages (e.g., Crow (Siouan), Tsúùt'ina (Athabaskan), etc.) that have unexpectedly developed tone.

\section{Morphology and Syntax}

Case is a grammatical category whose value reflects the grammatical function performed by a noun or pronoun in a phrase, clause, or sentence. For instance, the eight historical Indo-European cases are traditionally defined as follows ${ }^{39}$ : the nominative case indicates the agent of an action, the accusative

Plains Algonquian group, which appears to have developed pitch accent or even tonal systems.

${ }^{39}$ The correspondences are just rough descriptions since the precise case distinctions may vary from language to language and are often quite complex. case the patient, the dative case the recipient or beneficiary, the genitive case possession, the ablative case movement from something or cause, the vocative case the addressee, the locative case the location, and the instrumental case the object used in performing an action.

The fact that a morphological case can be marked on heads or dependents leads to the distinction between head-marking and dependent-marking languages (Nichols, 1986). Dependent-marking languages have grammatical markers showing agreement and case government between the constituents on dependents, rather than on heads.

Some languages, such as modern-day English, Spanish and French, have largely lost their morphological case systems, only retaining some case distinctions in personal pronouns (e.g., "I/ me" in English, "Yo/me/(a) mí" in Spanish, or "il/le/ lui" in French) or interrogative/relative pronouns (e.g., "who/whom" in English), but not in nouns. By contrast, other languages like German ${ }^{40}$ still have extensive morphological case systems, with pronouns, adjectives, determiners, and sometimes nouns all inflecting to indicate their case. German has four different morphological cases: nominative, accusative, dative, and genitive:

(89) German:

Mein Bruder ist sehr gut.

${ }^{40}$ German is predominantly dependent-marking as cases are mostly marked on pronouns, articles and adjectives, and less so on nouns. 
1SG:NOM brother.NOM.SG be.PRES.3SG:S very good

'My brother is very good.'

(90) German:

Maria liebt meinen Bruder.

Maria.NOM.SG love.PRES.3SG:S 1SG:ACC.MASC brother.ACC.SG 'Maria loves my brother.'

(91) German: Maria gab meinem Maria.NOM.SG give. PAST.3SG:S 1SG:DAT.MASC Bruder ein Buch.

brother.DAT.SG a.ACC.NEUT book.ACC.SG

'Maria gave my brother a book.'

(92) German:

Maria mag meines

Maria.NOM.SG like.PRES.3SG:S 1SG:GEN.MASC

Bruders Haus.

brother.GEN house.ACC.NEUT

'Maria likes my brother's house.'

Conversely, in head-marking languages such as Hungarian, case marking occurs predominantly on the noun, the head of the noun phrase:

(93) Hungarian:

Az én fiútestvérem nagyon jó.

the my brother .nom.sg very good

'My brother is very good.'

(94) Hungarian: Mária szereti az én fiútestvéremet.

Maria.nom.sg love.pres.3g:s the my brother.acc.sg

'Maria loves my brother.'

(95) Hungarian: Mária odaadott egy könyvet az én Maria.nom. sg give.past.3sg:s a book.acc.sg the my

testvéremnek.

brother.dat.sg

'Maria gave my brother a book.'

(96) Hungarian: Márianák tetszik az én fiútestvérem

Maria.dat.sg like.pres.3sg:s the my brother.gen háza.

'Maria likes my brother's house.'

Algonquian languages are also examples of headmarking languages with all inflection for grammatical relations being realized on the verb and avoiding oblique nominals by means of the formation of applicative constructions. The portmanteau affixes on the Algonquian verb enable us to distinguish the person, number, obviation and grammatical function or semantic role of the different arguments. The latter property is provided by the direct/inverse system, which is widely understood to involve different grammar for transitive predications according to the relative positions of their agent and their patient on the person hierarchy $2^{\text {nd }} .>1^{\text {st }} .>3^{\text {rd }} .>4^{\text {th }}$. $>$ Inanimate, which is, in turn, a combination of person, animacy, and topicality properties specific to a given participant. The direct construction is therefore used when the most agent-like of the transitive clause outranks the most patient-like in the person hierarchy, and the inverse is used when the argument possessing more patientlike qualities outranks the one with more agent-like properties, as shown in section 1 by examples ( 3 and 4).
On the one hand, direction (direct/inverse) marking has been generally considered as functionally equivalent to the distinguishing function of case marking since it enables subjects and objects, which are not otherwise overtly distinguished in Algonquian by case marking on nouns or different pronominal affixes, to be identified. On the other hand, owing to the fact that the existence of directinverse morphosyntax is usually accompanied by the proximate-obviative distinction, it is not unusual to find references to the obviative marking in Algonquian languages as "obviative case" marking. However, this does not seem to be an appropriate denomination. Firstly, the obviative third person is a grammaticalperson marking that distinguishes a non-salient (obviative) third-person referent ${ }^{41}$ from a more salient (proximate) third-person referent in a given discourse context. This distinction works as follows: in cases where a sentence or discourse context has more than one third person referent, the most salient or topical entity is marked as proximate and any other, less prominent, participants are marked as obviative. The obviative referent is always the marked form - its status is marked with a special marking on the noun and reflected in the verbal inflection -, with the proximate usually remaining unmarked:

(97) Arapaho:

Hinén nonoohówoot hiséin.

hinén ic+noohób+oot hísei-in

man (3)+see.vta-3:4 woman.obv

'The man saw the woman.'

(98) Blackfoot:

akííwa ikákomimmiiwa imitááyi.

aakíi-wa $\emptyset+$ +waakomimm+yiiwa imitáá-yi

woman-prox (3)+love.vta-3:4 dog-obv

'The woman loves the dog.'

(99) Cheyenne:

Vé’ho'e na'èstse ésevono énáhóho.

Vé’ho'e na'èstse ésevono é-ná'h-óho

white.man one female.buffalo.obv (3)-kill.vta-3:4

'The white man killed a buffalo.'

(100) Gros Ventre:

'Onóh'ihiih tiikyó'oniitéhiibsok'i 'íeihon'.

onśh'ihiih ic+tikyó' oníííh-niitéhiib-sok'i 'í⿴eih-on'

boy (3)+always-help.vta-3:4 girl.obv

'The boy always helps the girl.'

For example, in this sentence, there are two thirdperson referents but one of them is proximate so the other has to be obviative. This choice is not random, but depends on which one the speaker considers more central to the story. Additionally, the verbal inflection in every sentence indicates a proximate subject acting on an obviative object. Consequently, this type of grammatical marking is related to the pragmatic

\footnotetext{
${ }^{41}$ The obviative is sometimes referred to as the fourth person.
} 
properties of the referents, rather than their syntactic function, so it should not be referred to as a case.

Secondly, this assumption is supported by the fact that a shift in the proximate/obviative status does not alter the grammatical relationship between the participants and the predicate:

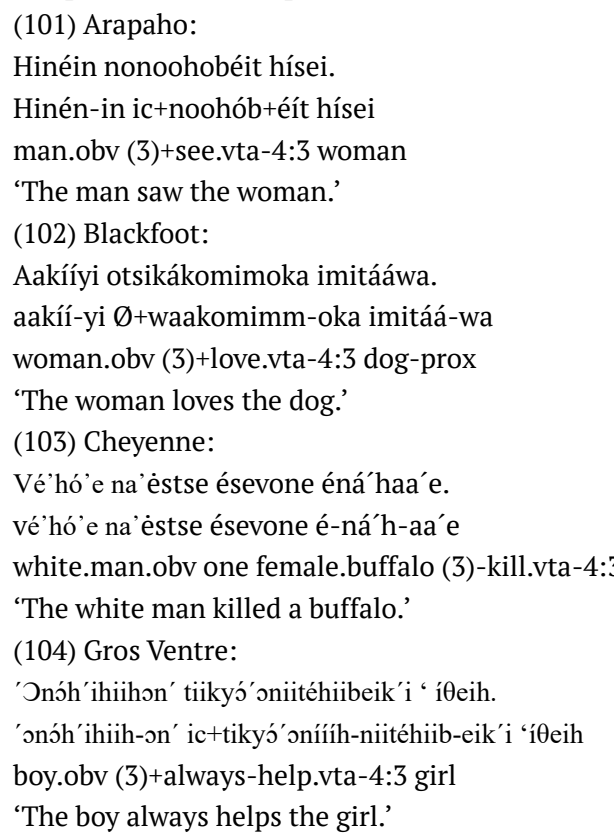

In this other example, the participants have swapped the discourse-pragmatic status of the participants, but the proximate referent continues to be pragmatically more salient than the obviated referent and the verbal inflection in every sentence indicates an obviative subject acting on a proximate object. Thus, a comparison between the two former examples illustrates that a shift from proximate to obviative in a specific participant does not lead to a change in its syntactic function. Although both referents have swapped their status regarding the proximate/ obviative distinction, they continue to function syntactically as the agent and patient - or, to be more accurate, (unaffected) theme or beneficiary, depending on the example - of the sentence respectively.

Unlike Algonquian languages, in languages such as English, German, Spanish, and French the main way of avoiding coreferentiality between multiple thirdperson referents is through gender distinction and the lack of a reflexive pronoun, as illustrated by the contrast between "she hurt herself", where the presence of the reflexive pronoun ensures coreferentiality between the two third person participants, and "she hurt her/ him", where it is clear that there are two third persons because of the absence of the reflexive pronoun or because they are of different genders.

In summary, the concept of case as a system for the grammatical marking of arguments to define the type of relationship they bear to their predicates, should be distinguished from the obviation system or the proximate/obviative distinction, another type of grammatical marking, which is concerned with the differentiation of multiple third person participants in the same context in accordance with their pragmatic status. Although the correlation between the case, semantic role, and pragmatic status of participants seems clear since a noun marked with the nominative case usually performs the role of agent, which is generally associated with proximate status, and a noun marked with the accusative case usually has the semantic role of patient, which normally receives obviative marking, case is a morphological notion, which is associated with the syntactic properties of constituents, rather than a semantic or pragmatic notion. Thus, just as we should distinguish case from semantic role assignment (for example in a sentence like "He fell down" where the nominative case is not aligned with the semantic role of agent), it should not subsume obviation marking, which is closely related to the discourse-pragmatic status of every participant within a particular context.

\section{Information Structure}

The term "Information Structure" has been traditionally defined as a grammatical phenomenon related to the way that information is distributed syntactically within a sentence and revolves round two concepts: what the addressee already knows and what $\mathrm{s} / \mathrm{he}$ is expected to know as a result of the communication of a particular message by the addresser. The basic notions in information structure are known as theme and rheme (Ammann, 1928), topic and comment (Hockett, 1958), presupposition and focus (Chomsky, 1971), background and focus (Chafe, 1976), old/given and new (Halliday, 1967), and topic and focus (Sgall, Hajičová and Benešová, 1973). The concepts "theme" and "rheme" have undergone an evolution in their definition from their conception by Ammann, who used them to refer basically to the distinction between subject and predicate, until their approximation to the concepts "topic" and "comment" by the newer Prague School, namely as the entity that identified by a speaker and the information that is given about that entity. The dichotomy presupposition-focus provides the informational partition of the sentence with a semantic interpretation whereby the focus is the element containing the intonation center and the presupposition is the part of the remainder of the sentence. Background represents the information that the addressee presumably already knows and focus indicates that part of an utterance contributes new, non-derivable, or contrastive information. Givenness indicates that the denotation of an expression is present in the immediate context of the utterance while newness adds unknown information about that 
expression. Topic is what the sentence is about and focus is what is predicated about that topic.

In an attempt at simplification, which intends to relate all these concepts one to another, the information structure of a clause is very commonly considered to comprise only two types of discoursepragmatic status: the topic or theme of a sentence, which indicates what the sentence is about (i.e., pragmatic presupposition), and focus, comment, or rheme, which represents what is said about the topic (i.e., pragmatic assertion). Although the boundary between these two terms depends on the grammatical approach taken in the analysis and different types of topic and focus are also usually distinguished, both terms correspond very roughly to the notions of given and new information respectively, as anaphorically recoverable information and textually and situationally non-derivable information are by definition old and new, respectively. Although different languages realize topic and focus in different ways and do so most commonly through a particular word order and the use of a special intonation, the tendency to place topicalized constituents at the beginning of a sentence (topic fronting) and highlight focalized elements by prosodic and syntactic means is widespread.

Unlike languages such as English or French, which have a rigid word order, there are languages like Nunggubuyu (Gunwinyguan: northern Australia), and perhaps to a certain extent Russian, Polish, Czech, German, Dutch, Chinese, and Japanese whose case systems allow the order of arguments to be altered without changing the arguments' grammatical relations.

Word order in Algonquian languages is also apparently extremely flexible as it allows all kinds of possible combinations as to the position of the major constituents, that is, subject, verb and object (SOV, VSO, VOS, OSV or OVS), so that the syntactic functions cannot be deduced from their position in the clause, as illustrated by the following examples of monotransitive constructions in Cheyenne:

(105) Cheyenne:

a. Ného'ééhe évéstähémóho hetanóho. -> SVO

ného'ééhe é-véstàhém-ó-ho hetanóho

my.father (4)-help.vta-4:5-sg.a+5.p man.obv

'My father helped the man.' (by Redfox \& Leman in Leman, 1980a, p. 19)

b. Tse'tohe kảse'ééhe sétöhkeho éxhestanóhoone. -> SOV

tse'tohe kảse'ééhe sétöhkeho é-x-hestan-óhoon-e

deic young.woman rope (3)-past-take-with.hand.vti-3:I

'This young lady took the rope.' (by Petter \& Leman, in Leman, 1980a, p. 63)

c. Móme'évèhéheškéhévóhta nema'kaatóhkonéhanótse mó-me'-évè-hé-heškéhévóht-a ne-ma'kaatóhkonéhanótse clm-surely-about-asp-dirty.vti-3:I (dub) our-buckets tsé'tóhe. -> VOS deic

'This one would surely dirty our buckets.' (by Howlingcrane \& Leman, in Leman, 1980a, p. 38)

d. Éstanèšěševátamósesto(ho) hátšeške háhkotaho.->VSO

é-h-ta-něšěševátamósest-o(-ho) hátšeške háhkotaho

(3)-past-have.pity.on.vta-3:4-sg.a+4.p ant grasshopper.obv

'The ant had pity on the grasshopper.' (by Flyingout \& Leman, in Leman, 1980a, p. 28)

e. Moméheome éhnèhna'haevó nótảxévé'hó'e.-> OVS

moméheome é-h-nèh-na'h-ae-vó nótảxé-vé'hó'e.

whole.families (3)-past-?-kill.vta-4:33-4.a+33.p warrior.

whiteman.obv

'The soldiers killed whole families.' (by Strangeowl \& Leman, in Leman,1987, p. 37)

f. Kähamaxè néhe he'e étamöheananòtse. $\quad->$ OSV

kähamaxè néhe he'e é-ta-möheana-nò-(o)tse

sticks deic woman (3) gather.vti-3:II+II.p-II.p

'That woman gathered up the sticks.' (Leman, 1991, p. 3)

The fact that the change in the linear ordering of the sentence constituents does not entail a significant change in the meaning of the whole sentence by itself can also be illustrated in ditransitive constructions like those in Blackfoot, below:

(106) Blackfoot:

a. Nitohkotawa ni'sa ponokaomitai.

nit-ohkot-awa ni's-wa ponokáómitaa-yi

(1)-give.vta-1:3 older.brother-prox horse-obv

'I gave my brother a horse.'

b. Ni'sa nitohkotawa ponokaomitai.

ni's-wa nit-ohkot-awa ponokáómitaa-yi

older.brother- prox (1)-give.vta-1:3 horse-obv

'My brother I gave a horse.'

c. Ponokaomitai nitohkotawa ni'sa.

ponokáómitaa-yi nit-ohkot-awa ni's-wa

horse-obv (1)-give.vta-1:3 older.brother-prox

'A horse I gave my brother.'

Although referential phrases are not normally explicitly expressed in natural discourse, there are situations where two (or even three) third person participants are involved in the same discourse tract. In these cases one of the third person arguments is normally marked as proximate, which is pragmatically more salient or prominent ${ }^{42}$, and all others are marked as obviative, which are less salient. The choice of which third person participant is proximate and which is obviative is open to the speaker. However, there is a general tendency for humans to have priority over animals and inanimate participants to be marked as proximate.

Although it is generally accepted (Hawkinson \& Hyman, 1974) that agents are inherently more prominent or salient than patients, it is of note that the concepts proximate and obviative do not correspond

\footnotetext{
${ }^{42}$ The concept of prominence or salience appears to subsume a combination of the discourse-pragmatic factors such as specificity, topicality, emphasis, etc.
} 
to the semantic roles of agent and patient either:

(107) Gros Ventre:

a. 'Inén'i nii'áaanibook'i 'í⿴aa'n's.

'inén'i ic+ni'áaanib-sok'i 'îaa'-n'o

man (3)-love.vta-3:4 woman-obv

'The man loves the woman.'

b. 'Î́aa' nii'áaanibeik'i 'inén'in'o.

'í⿴aa' ic+ni'áaanib-eik'i 'inén'i-n's

woman (3)-love.vta-4:3 man-obv

'The man loves the woman.'

As we can see from the examples given above, the semantic role of agent can be realized by both a proximate referent such as 'inén'i 'man' (107a) and an obviative referent like 'inén'in's 'man' (107b). Similarly, the semantic role of patient can be played by both a proximate argument like 'í $\theta a a$ ' 'woman' (107b) and an obviative argument such as 'íaa'n's 'woman' (107a). This dual behaviour of both proximate and obviative arguments is reflected in the direct/ inversion opposition: the direct construction (3:4) is used if the agent is more topical or ontologically salient (=proximate) than the patient (=obviative), and the inverse if the patient is more topical or ontologically salient (=proximate) than the agent (=obviative).

Likewise, although it is also generally assumed (Osgood \& Bock, 1977) that more prominent or more salient items appear earlier in a sentence - and indeed there is a noticeable trend in Plains Algonquian languages in which proximate referents usually precede obviative -, we can see that both proximate and obviative arguments can also occur in a pre- or postverbal position within a sentence:

(108) Arapaho:

a. Hísei nonooohówoot hinénin.

isei(n) ic+noohób-oot inenin

woman (3)-see.vta-3:4 man.obv

'The woman sees the man.' (Cowell \& Moss, 2008: 350)

b. Hinénin nonooohówoot hísei.

inenin ic+noohób-oot isei(n)

man.obv (3)-see.vta-3:4 woman

'The woman sees the man.' (Cowell \& Moss, 2008, p. 351)

Furthermore, although it seems a more reliable correlation owing to the fact that they mark discourse prominence and, therefore, have a closer relationship to the information structure than to the syntax or semantics, proximate and obviative statuses do not correspond to the notions of topic and focus or vice versa. On the one hand, proximate referents may be either topical (109) or focal (110):

(109) Blackfoot:

Myániwa ana ínoyiiwa ani aakí́koani

myani-wa an-(w)a $\emptyset$-ino-yiiwa an-(y)i aakiikoan-(y)i

Mary-prox deic-prox (3)-see.vta-3:4 deic-obv girl-obv

'Mary, she saw that girl' (Bliss, 2005, p. 67)

(110) Blackfoot:

Ama nínaawa annohk ááwayakiiwahk ani am-(w)a ninaa-wa annohk $\emptyset$-aawayaki-(yi)iwahk an-(y)i deic-prox man- prox who (3)-hit.vta-3:4 deic-obv

'It was this man who hit him' (Bliss, 2005, p. 68)

In (109), the proximate referent myániwa 'Mary' is topicalized and in (110), the proximate referent ama ninaawa 'this man' is contrastively focused, which proves that proximate forms can be used to refer to both topical and focal constituents.

On the other hand, obviative arguments may also be topical (111) or focal (112):

\section{(111) Cheyenne:}

Hénáá'énèse é-amó'enánoho

hénáá énèse é-am-ó en-án-oho

something .obv (3)-along-take.vti-by.hand-3:4

'Something, he was rolling along it.' (Leman, 1980, p. 29)

(112) Cheyenne:

éhma'xenėsó'enomėhoo' o. mó-nėsé-hanevóhe

é-h-ma'xe- nèsó'enome-hoo'o mó-nèsé-hanevóhe

(3)-past-really-snore.vai-3(med) clm-be.vai-4 (dub)

né=hetane

néhe=hetane

deic $=$ man

'He was really snoring. Here, that was him, that man.' (Leman, 1987, p. 270)

In (111), the obviative indefinite pronoun hénááénèse, which denotes something whose identity is unknown to the speaker, is topicalized and in (112), the verbal form mó-nésé-hanevóhe includes the typical verbal prefix of the dubitative ${ }^{43}$ mode mó-, a copular verb nésé, which is commonly used to emphasize a specific participant, and the pronominal affix -hanevóhe, which refers to a focalized obviative argument.

Consequently, although languages with an apparently flexible word order are usually called free word order languages, this term is misleading since the choice of word order is normally governed by certain pragmatic factors. For this reason, the concept 'discourse configurationality' (Hale, 1983; Jelinek, 1984; Kiss, 1995) was developed to describe languages where constituent order is primarily determined by the discourse-pragmatic status of participants, so that languages that attach more importance to the encoding of discourse-pragmatic functions than semantic roles or syntactic functions are commonly referred to as discourse-configurational languages.

In some of these languages, such as Chinese and Japanese, word order largely reflects a topic-focus (or theme-rheme) canonical word order so they are sometimes referred to as topic-prominent languages. By contrast, in other languages like Ojibwe (Tomlin \& Rhodes, 1992, Valentine, 2001; Morse, 2012), and

\footnotetext{
43 The dubitative mode is commonly used to express doubt, uncertainty, or speculation because the information to be transmitted is known to have occurred but has not actually been witnessed.
} 
possibly Menominee (Johnson, Macauley, Rosen \& Wang, 2015; Shields, 2004) and Meskwaki (Dahlstrom, 2003), word order represents the reversed structure, namely focus-topic, so they could be called focusor comment-prominent languages. Finally, there are languages like Czech that, despite showing a preference for topic over focus, permit both orders, which are then distinguished by intonation.

Plains Algonquian languages also seem to lack a clear dominant structure, that is to say, word order does not appear to mark a definite topic-focus or focustopic structure consistently. At least in narrative, which is the best documented form of Algonquian discourse, the vast majority of sentences consists simply of a verb, with the various other nominal participants marked on the verb but not explicitly mentioned in the sentence (there are also typically peripheral elements, such as particles, adverbials, and the like). When the sentence contains an NP, this usually occupies the post-verbal position, which seems to be the unmarked syntactic position. The fact that an NP may occur preverbally indicates greater pragmatic saliency for that participant, which generally takes place when the situation involves topic continuation or a contrastive element:

(113) Arapaho:

line 80: "Hiiko," heehehk, "toh'uusiitenein heisonoonin,"

hee3oohok

iiko ee-hehk toh-iisiiten-ein eisonoonin ee3-oohok no say.vai-3 because-catch.vta-3:2 our.father ay.vta-3:4(subj)

'"No," he said, "because our father caught [and tamed] you," he said to him.

line 81: Nohci' “heetih'iinikotiino'”

noh=ci' eetih-iinikotii-no'

and=again let.it.be-play.vai-12

'And once again [the first boy said], "Let's play."

line 82: "hiiko, heisonoonin toh'uusiitenein," hee3oohok.

iiko eisonoonin toh-iisiiten-ein ee3oohok

no our.father because-catch.vta-3:2 say.vai-3:4(subj ${ }^{44}$ )

'No, because our father caught [and tamed] you," he said to him [again]'

(Cowell \& Moss, 2008, p. 407, lines 80-82)

In this dialogue the topical element heisonoonin 'our father', which is introduced in line 80, reappears again in line 82 , this time occupying a preverbal position at the front of the sentence.

(114) Arapaho:

line 25: 'oh hú'un honóuuneenóúu $u$

'oh i'in ic+ouuneenoo-'i

but deic [bones] (I)+difficult.vii-ii

'But those bones are difficult [to lift].'

line 26: Wohéí néhe'=ísei yee bí́to'ówu' ne'i khoo noh'óéno' wohei nehe'=isei(n) yee biito' owu-' ne'i khoo noho'en-o'

${ }_{44}$ Besides being obligatory in irrealis sentences, the subjunctive mode also has an evidential use in the narration of traditional stories. well deic woman yes earth-sg then well lift.vti-3

'Well, this woman well [she put] earth [on her hands] and then she lifted [the bones]' (Cowell \& Moss, 1998, p. 402, lines 25-26)

As we can see from this other excerpt, a focalized element such as néhe'=ísei 'this woman' occurs in clause-initial position.

A familiar or given topic and a contrastive topic or focus represent only two possible statuses for a clause-initial constituent in these languages, but other options such as instances of topic shift and resumptive topics can also be associated with the leftmost position in a sentence, as we can see from the following discourse in Cheyenne:

(115) Cheyenne:

line 1: Tá'tóhe hetane hestóhkoxxe étaévaameno'eohtse

tá tóhe hetane he-stóhkòxe é-ta-éva-ame-no'e-ohtse

deic man his-axe (3)-away-back-along-with-go.vai.3

'That man carried his axe.'

line 2: Étaévaameno'eohtse hestóhkòxe

é-ta-éva-ame-no'e-ohtse he-stóhkoxe

(3)-away-back-along-with-go.vai.3 his-axe

'He carried his axe.'

line 3: Éévaaseno'eohtse hestóhkỏxe

é-éva-ase-no'e-ohtse he-stóhkòxe

(3)-back-off-with-go.vai.3 his-axe

'He carries off his axe.'

line 4: Tsé tóhe kảsovááhe héne hóhkỏxéso éameno’ehne

tsé 'tóhe kảsovááhe héne hóhkỏxé-so é-ame-no'e-hne

(3)-back-off-with-go .vai.3 deic axe-dim (3)-along-with-walk. vai.3

'This young man carried his hatchet.'

line 5: Hóhkỏxe énóehne

hóhkòxe é-no'e-hne

axe (3)-with-walk.vai.3

'He is carrying his axe.' (Leman, 1991, pp. 69-70)

In line 1 it is possible to observe a topic shift: whereas in the former discourse tract the story is about a dog, now the participant tá tóhe hetane "that man" becomes the main topic. Additionally, we can find the first mention of another participant, namely hestóhkòxe "axe". In line 2 a new verb, the Cheyenne equivalent to "carry", is introduced in the context, and in line 3 the verb, slightly modified this time, occurs again in clause-initial position. Line 4 shows a new topic shift whereby a new participant, namely tsé'tóhe kàsovááhe "this young man", appears at the front of the sentence. Particularly striking is that this line introduces a further participant - héne hóhkoxéso 'his hatchet' - but occurs in second position, probably due to the fact that it is not considered to be as relevant as the former. Finally, in line 5 there seems to be a resumptive topic because the clause-initial constituent hóhkoxe '(his) axe' has already been mentioned above.

Taking all this evidence into account, it would seem reasonable that, in order to detect the dominant word order pattern in Plains Algonquian languages, 
we should find out what kind of pragmatic factors are in play. Predicate focus, which contains a topical constituent and an assertion made about that topic, is generally considered to be the unmarked type of focus structure in most languages. However, the evidence provided by these Algonquian languages appears to suggest a tendency to place any information that the addresser considers relevant to the addressee preverbally. We might therefore consider the concept of "newsworthiness" the determinant pragmatic factor in the syntactic structure of information packaging in these languages. According to Mithun (1987), the term "newsworthiness" relates to the pragmatic salience or prominence given by a speaker to a specific constituent in a discourse span because $\mathrm{s} / \mathrm{he}$ considers this information (whether old or new) important from the hearer's perspective. Thus, although this concept can also be affected by the notions of presupposition and assertion, it should preferably be linked to the concept of relevance: the speaker or writer's choice of information that seems newsworthy is closely related to empathy, that is the capacity to recognize the feelings, emotions, beliefs, and opinions experienced by the addressee. ${ }^{45}$ This would also suggest that if we desire to continue using the terms topic or theme and focus or comment or rheme to refer to the two major discourse-pragmatic statuses participants can have in a communicative event in these languages, it might be reasonable to suppose that the concepts of focus and topic must underlie the distinction between newsworthy and non-newsworthy information, a criterion that could be regarded as a mixture of the attributes of aboutness, informativeness, update, discourse-newness, and hearer-newness - to borrow Mycock \& Lowe's (2014) terms - rather than purely related to the notions of assertion or presupposition.

In conclusion, syntax in Algonquian languages such as Cheyenne, Blackfoot, Arapaho and Gros Ventre appears to be largely a question of pragmatics, since word order in these languages has a discourse function: that is to say, their word order is oriented towards the encoding of the discourse-pragmatic status of the participants involved in the context, so they are appropriately referred to as discourseconfigurational. Furthermore, although it is true that the clause constituents in these languages are ordered according to their discourse-pragmatic properties, these are more related to newsworthiness than to the distinction between givenness (i.e., what is known vs. what is new) and aboutness (i.e., what an utterance is

\footnotetext{
45 An important correlate of the importance attributed to the addressee in these languages is reflected in the person - salience hierarchy $2^{\text {nd }} .>1^{\text {st }} .>3^{\text {rd }} .>4^{\text {th }}$. $>$ Inanimate, which determines the distinction between the core arguments of a predicate on the basis of their semantic role. The only exception seems to be Blackfoot, whose hierarchy appears to rank the first person over the second.
}

about vs. what is said about it).

\section{Conclusion}

The main aim of this article is to describe the distinctive grammatical properties shown by Plains Algonquian languages. However, the important thing about these distinctive properties is not only that they show us how different these languages are from other more familiar languages, but also that they cannot be accounted for appropriately if we do not resist the temptation to use terms adopted from these more familiar languages to refer to concepts that are perceived as functional equivalents in Native American languages when in fact, despite being to a greater or lesser extent related, the value of these concepts is significantly different in these minority languages. This can be illustrated by several examples covering all areas of grammar such as: 1) the use of the terms "subject" and "object" to refer to grammatical or syntactic relations when there are no grounds for assuming that they exist at all in these languages; 2) the problem that arises when we have to choose between the labels "argument" and "adjunct" to refer to semantic arguments not crossreferenced by pronominal affixes on a particular verbal complex; 3) the difficult task of identifying the number of categories or, more precisely, the decision regarding which is the most suitable criterion on which we should build in order to identify the number of categories in Plains Algonquian languages; 4) the issue regarding the interpretation of the prosodic systems exhibited by these languages in their current state of development as either stress-accent, pitchaccent or tonal; 5) the consideration of the proximate vs. obviative system as a further type of case or not; and 6) the examination of the information structure in these languages through a different interpretation of the concepts "topic" and "focus", which are not only associated with the traditional notions of givenness or aboutness but also to others such as relevance or salience based on empathy for the addressee.

Consequently, in an attempt to suggest how potential problematic areas of grammatical description in Plains Algonquian languages could be tackled more adequately, I propose the use of the following terms ${ }^{46}$ : 1. "Privileged Syntactic Argument" instead of "subject"; an equivalent for the grammatical function of "object" would be completely unnecessary.

${ }^{46}$ I do not claim any originality with these proposals, as I am aware that all of them may already have been used to describe the grammar of Algonquian languages. My only aim is to highlight the grammatical distinctiveness of these languages and the importance of finding terms that ensure accuracy in their description. 
2. "Argument-Adjunct", "semi-core argument", or "derived argument" for semantic arguments not cross-referenced by pronominal affixes.

3. The identification of just three categories, namely verb, noun, and particle, if we tackle the study of categories in these languages from the perspective of sentence-syntax, or a higher number of categories (e.g., verb, noun, adjective, adverb, connector, adposition, demonstrative, particle), if we take word-syntax into account, thereby treating morphemes as words.

4. The consideration of Plains Algonquian languages as "transitional languages" rather than "pitchaccent languages" or "tonal languages" in terms of the properties exhibited by their current prosodic systems.

5. "Proximate/obviative system" or "obviation system" instead of "obviative case".

6. The assumption that Plains Algonquian languages should be considered newsworthy-first languages in the sense that they are languages in which the syntax is organized to emphasize newsworthy information - non-newsworthy information structure of the sentence. Another option would be to consider them to be focus-prominent languages if we understand the concepts of "topic" and "focus" from a broader perspective, that is by equating focus with newsworthy information chosen by the addresser to communicate firstly to the addressee because s/he thinks it will be of great relevance, and topic with non-newsworthy information, that is information that the addresser considers less relevant to the addressee.

Finally, we should also note the influential role played by pragmatics in most areas of Algonquian grammar since pragmatic factors pervade much of Algonquian morphosyntax (e.g., the selection of a privileged syntactic position in main clauses, the choice of the semantic arguments to be incorporated in verbs and the concomitant variation shown by verbs in terms of transitivity, etc.), semantics (i.e., the factor of pragmatic prominence or salience driving the speaker's choice as to which argument to use in a context involving two third person participants, whether they will act as agent or patient), and information structure (i.e., the influence of the discourse-pragmatic concept of "newsworthiness" when it comes to structuring the way that information is transferred in discourse).

In conclusion, the fact that the grammar of a specific language - in this case illustrated by the Plains Algonquian languages - is different in many areas when compared with a widely spoken language, such as English, appears to imply that the concepts applied to its description will - albeit to a greater or lesser extent too - differ, so that the terms used to account for those distinctive properties will also probably differ from those used in the description of other languages with different grammatical characteristics.

\section{Acknowledgements}

This work was supported by the Arts and Humanities Research Council in the UK (project number AH/M011291/1). I would like to express my thanks to Andrew Cowell, Donald Frantz, and Wayne Leman for their invaluable help, as well as to Ralph Redfox and Richard Littlebear for having kindly and patiently shared their knowledge of the Cheyenne language with me. Of course any errors are entirely my own responsibility.

\section{References}

Ammann, H. (1928). Die menschliche rede. Sprachphilosophische untersuchungen 2. Teil: Der satz [The human language. Language-philosophical investigations 2: The clause sentence]. Darmstadt, Germany: Wissenschaftliche Buchgesellschaft.

Arka, I. W. (2005). The core-oblique distinction and core index in some Austronesian languages of Indonesia. Keynote paper presented at the International ALT VI (Association of Linguistic Typology) conference, Padang, Indonesia.

Baker, M. (1996). The polysynthesis parameter. Oxford, UK: Oxford University Press.

Beckman, M. E. (1984). Toward phonetic criteria for a typology of lexical accent (Unpublished $\mathrm{PhD}$ thesis). Cornell University, Ithaca, New York.

Beckman, M. E. (1986). Stress and non-stress accent. Dordrecht, Netherlands: Foris.

Biber, D., Stig J., Leech, G., Conrad, S., \& Fineganet, E. (1999). Longman grammar of spoken and written English. Essex UK: Pearson Education.

Bliss, H. (2005). Topic, focus, and point of view in Blackfoot. In J. Alderete et al. (Eds.), Proceedings of the 24th West Coast Conference on Formal Linguistics (pp.61-69). Somerville, MA: Cascadilla Proceedings Project.

Bliss, H. (2008). Structuring information in Blackfoot: Against the $\mathrm{A}^{\prime}$-agreement analysis of crossclausal agreement. Proceedings of the 2008 annual conference of the Canadian Linguistic Association. Retrieved from: http://homes.chass.utoronto. ca/ cla-acl/actes2008/CLA2008_Bliss.pdf

Bloomfield, L. (1946). Algonquian. In H. Hoijer et al. (Eds.), Linguistic structures of Native America (pp. 85-129). New York, NY: Viking Fund.

Bybee, J., Chakraborti, P., Jung, D., \& Scheibman, J. (1998). Prosody and segmental effect some paths of evolution for word stress. Studies in Language, 
22(2), 267-314.

Campbell, L. (1997). American Indian languages: The historical linguistics of Native America. New York, NY: Oxford University Press.

Chafe, W. (1976). Givenness, contrastiveness, definiteness, subjects, topics, and point of view. In Ch. N. Li (Ed.), Subject and topic (pp. 25-55). New York, NY: Academic Press.

Chomsky, N. (1971). Deep structure, surface structure and semantic interpretation. In D. D. Steinberg \& L. A. Jakobovits (Eds.), Semantics: An interdisciplinary reader in philosophy, linguistics and psychology (pp. 183-216). Cambridge, UK: Cambridge University Press.

Chomsky, N. (1981). Lectures on government and binding. Dordrecht, Netherlands: Foris.

Chomsky, N. (1986). Knowledge of language: Its nature, origin and use. New York, NY: Praeger.

Clark, M. (1988). An accentual analysis of Zulu. In H. G. van der Hulst \& N. Smith (Eds.), Autosegmental studies on pitch accent (pp. 51-79). Dordrecht, Netherlands: Foris.

Conner, J. E. (1968). A grammar of standard English. Boston, MA: Houghton Mifflin Company.

Comrie, B. (1978). Ergativity. In W. P. Lehmann (Ed.), Syntactic typology: Studies in the phenomenology of language (pp. 329-394). Austin, TX: University of Texas Press.

Comrie, B. (1989). Language universals and linguistic typology ( $2^{\text {nd }}$ ed.). Chicago, IL: University of Chicago Press.

Corral Esteban, A. (2014). An analysis of transitivity in Cheyenne. Acta Linguistica Hungarica, 61(4), 379422.

Cowell, A., Taylor, A. R., Brockie, T., \& Stiffarm J. (2004). Gros ventre grammar sketch. Boulder, CO: Center for the Study of Indigenous Languages of the West (CSILW).Cowell, A., \& Moss, A. Sr. (2005). Hinnóno'éínoo3ítoono / Arapaho historical traditions told by Paul Moss. Winnipeg, Canada: University of Manitoba Press.

Cowell, A., \& Moss, A. Sr. (2008). The Arapaho language. Colorado, CO: University Press of Colorado.

Dahlstrom, A. (2003). Sentence-focus in Meskwaki. Paper read at the 35th Algonquian Conference, London, Ontario, Canada.

Denzer-King, R. (2009). The distribution of $/ \mathrm{s} /$ in Blackfoot: An optimality theory account. Theses, Dissertations, Professional Papers, 981.

Dixon, R. M. W. (1979). Ergativity. Language, 55, 59138.

Dowty, D. (1991). Thematic proto-roles and argument selection. Language, 67, 547-619.

Dryer, M. S. (1986). Primary objects, secondary objects, and antidative. Language, 62, 808-845

Dryer, M. S. (1997). Are grammatical relations universal? In J. Bybee, J. Haiman and S. A. Thompson (Eds.), Essays on language function and language type: Dedicated to T. Givon (pp. 115-143). Amsterdam, Netherlands: John Benjamins.

Falk, Y. N. (2006). Subjects and universal grammar: An explanatory theory. Cambridge, UK: Cambridge University Press.

Foley, W. A., and van Valin, R. D. Jr. (1977). On the viability of the notion of "subject" in universal grammar. Proceedings of the 3rd annual meeting of the Berkeley Linguistics Society (pp. 293-320). Berkeley, CA: BLS.

Foley, W. A., and van Valin, R. D. Jr. (1984). Functional syntax and universal grammar. Cambridge, UK: Cambridge University Press.

Fountain, A. (2016). Arapaho accent. Coyote Papers: Working Papers in Linguistics from A-Z (pp. 29-38). Arizona, AZ: University of Arizona Linguistics Circle.

Frantz, D. G. (1971). Toward a generative grammar of Blackfoot (with particular attention to selected stem formation processes). Oklahoma, OK: University of Oklahoma.

Frantz, D. G. (1972a). Cheyenne distinctive features and phonological rules. International Journal of American Linguistics, 36, 6-13.

Frantz, D. G. (1972b). The origin of Cheyenne pitch accent. International Journal of American Linguistics, 38, 223-225.

Frantz, D. G. (1997). Blackfoot grammar. Toronto, Canada: University of Toronto Press.

Frantz, D. G., and Norma J. R. (1995). Blackfoot dictionary. Toronto, Canada: University of Toronto Press.

Gandour, J. T. (1978). The perception of tone. In V. Fromkin (Ed.), Tone: A linguistic survey (pp. 41-76). New York, NY: Academic Press.

Givón, T. (1995). Functionalism and grammar. Amsterdam, Netherlands: John Benjamins.

Goddard, I. (1974). An outline of the historical phonology of Arapaho and Atsina. International Journal of American Linguistics, 40(2), 102-116.

Goddard, I. (1979). Comparative Algonquian. In L. Campbell and M. Mithun (Eds.), The languages of Native America: Historical and comparative assessment (pp. 70-132). Austin, TX: University of Texas Press.

Goddard, I. (1994). The West-to-East cline in Algonquian dialectology. In W. Cowan (Ed.), Papers of the 25th Algonquian Conference (pp. 187-211). Ottawa, Canada: Carleton University.

Goddard, I. (1996). The description of the native languages of North America before Boas. In I. Goddard (Ed.), Handbook of North American Indians: Languages (Vol. 17, pp. 17-42). Washington, DC: Smithsonian Institution. 
Goddard, I. (2001). The Algonquian Languages of the Plains. In R. J. DeMallie (Ed.), Handbook of North American Indians (Vol. 13, pp. 71-79). Washington, DC: Smithsonian Institution.

Goldsmith, J. (1976). An overview of autosegmental phonology. Linguistic Analysis, 2(1), 23-68.

Grimshaw, J. (1990). Argument structure. Cambridge, UK: MIT Press.

Gussenhoven, C. (2004). The phonology of tone and intonation. Sound files. Cambridge, UK: Cambridge University Press.

Hale, K. (1983). Warlpiri and the grammar of nonconfigurational languages. Natural Language and Linguistic Theory, 1, 5-47.

Halle, M., and Jean-Roger, V. (1982). On the framework of autosegmental phonology. In H. G. van der Hulst and N. Smith (Eds.), The structure of phonological representation (Vol. 1, pp. 65-82). Dordrecht, Netherlands: Foris.

Halliday, M. A. (1967). Notes on transitivity and theme in English. Part 1, 2. Journal of Linguistics, 3, 37-81, 199-244.

Hawkinson, A., and Hyman, L. (1974). Hierarchies of natural topic in Shona. Studies in African Linguistics, 5, 147-170.

Hockett, Ch. F. (1958). A course in modernlLinguistics. New York, NY: Macmillan.

Hopper, P., and Thompson, S. A. (1980). Transitivity in grammar and discourse. Language, 56, 251-259.

Hyman, L. M. (1975). Phonology. New York, NY: Holt, Rinehart, and Winston.

Hyman, L. M. (1977). On the nature of linguistic stress. In L. M. Hyman (Ed.), Studies in Stress and Accent (pp. 37-82). Los Angeles, CA: University of Southern California.

Hyman, L. M. (2001). Tone systems. In M. Haspelmath, E. König, W. Oesterreicher, and W. Raible (Eds.), Language typology and language universals: An international handbook (Vol. 2, pp. 1367-1380). Berlin, Germany: Walter de Gruyter.

Hyman, L. M. (2006). Word-prosodic typology. Phonology, 23, 225-257.

Hyman, L. M. (2007). Universals of tone rules: 30 years later. Tones and Tunes, 1, 1-34.

Hyman, L. M. (2009). How (not) to do phonological typology: The case of pitch accent. Language Sciences, 31(2), 213-238.

Jakobson, R. (1939). Prinzipien der historischen phonologie [Principles of historical phonology]. Travaux du cercle linguistique de Prague, 4, 247-267.

Jelinek, E. (1984). Empty categories, case, and configurationality. Natural Language and Linguistic Theory, 2, 39-76.

Johnson, M., Macauley, M., Rosen, B., \& Wang, R. (2015). A survey of Menominee word order. In M. Macauley and J. Randolph Valentine (Eds.), Papers of the 43 $3^{\text {rd }}$ Algonquian Conference (pp. 154-178). New York, NY: State University of New York.

Kaneko, I. (1999). A metrical analysis of Blackfoot nominal accent in optimality theory (Unpublished doctoral dissertation). University of British Columbia, British Columbia, Canada.

Kaplan, R. M., and Bresnan, J. (1982). Lexical functional grammar: A formal system for grammatical representation. In J. Bresnan (Ed.), The mental representation of grammatical relations (pp. 173281). Cambridge, UK: MIT Press.

Keenan, E. L. (1976). Towards a universal definition of subject. In Ch. N. Li (Ed.), Subject and Topic (pp. 303-303). New York, NY: Academic Press.

Kiss, K. É. (1995). Discourse configurational languages. Oxford, UK: Oxford University Press.

Kroeger, P. (2004). Analyzing syntax: A lexical-functional approach. Cambridge, UK: Cambridge University Press.

Lahiri, A. (2001). Metrical patterns. In E. König and M. Haspelmath (Eds.), Language typology and language universals (pp. 1347-1367). Berlin, Germany: Mouton.

Leman, E. (1991). Word order of major constituents in Cheyenne narratives. Dallas, TX: Summer Institute of Linguistics.

Leman, W. (1980a). Cheyenne texts: An introduction to Cheyenne literature. Occasional Publications in Anthropology, Linguistics, Series No. 6. Museum of Anthropology. Greeley, CO: University of Northern Colorado.

Leman, W. (1980b). A reference grammar of the Cheyenne language. Occasional Publications in Anthropology, Linguistics, Series No. 5. Museum of Anthropology (Vol. 1, 2). Greeley, CO: University of Northern Colorado.

Leman, W. (1981). Cheyenne Pitch rules. International Journal of American Linguistics, 47(4), 283-309.

Leman, W. (1985). Cheyenne pronouns and pronominal forms. Retrieved from: http://www. cheyennelanguage.org/papers/Wayne\%20 Leman/Cheyenne\%20Pronouns\%20and\%20 Pronominal\%20Functions.pdf

Leman, W. (1987). Náévâhóóôhtséme / We are going back home: Cheyenne history and stories told by James Shoulderblade and others (Memoir 4). Winnipeg, Canada: Algonquian and Iroquoian Linguistics.

Leman, W., Fisher, L., Pine, L. Sr., and Sanchez, M. (2006). Cheyenne dictionary. Retrieved from: http:// www.cdkc.edu/cheyennedictionary/lexicon/main. htm

Leman, W., and Rhodes, R. (1978). Cheyenne vowel devoicing. In W. Cowan (Ed.), Papers of the Ninth Algonquian Conference (pp. 3-24). Ottawa, Canada: Carleton University.

Malchukov, A. L. (2005). Case pattern splits, verb types, 
and construction competition. In M. Amberber and H. de Hoop (Eds.), Competition and variation in natural languages: The case for case (pp. 73-117). Amsterdam, Netherlands: Elsevier.

Marantz, A. P. (1981). A theory of grammatical relations (Unpublished doctoral dissertation). Cambridge, UK.

Metallic, E., Cyr, D. E., and Sévigny, A. (2005). The metallic Migmaq-English reference dictionary. Paris, France: Les presses de l'Université Laval.

Milliken, S. (1983). Vowel devoicing and tone recoverability in Cheyenne. Working Papers of the Cornell Phonetics Laboratory, 1, 43-75.Mithun, M. (1987). Is basic word order universal? In R. S. Tomlin (Ed.), Coherence and Grounding in Discourse (pp. 281-328). Amsterdam, Netherlands: John Benjamins.

Mithun, M. (1999). The languages of Native North America. Cambridge, UK: Cambridge University Press.

Morse, S. (2013). Word order in Anishinaabemowin (Ojibwe) ditransitive constructions. Proceedings of the 44th Annual Algonquian Conference, Chicago, Illinois. Retrieved from: http:// artsites.uottawa.ca/algonquian $45 /$ doc/ Ojibwebasicwordorderandinfostructure1.pdf

Mycock, L., and Lowe, J. J. (2014). S-structure features for information structure analysis. Paper presented at the LFG14 conference, University of Michigan at Ann Arbor, Michigan, MI.

Needham, S., and Toivonen, I. (2011). Derived arguments. In M. Butt and T. H. King (Eds.), Proceedings of the LFG11 Conference. Carleton, Canada: CSLI Publications.

Nichols, J. (1986). Head-marking and dependentmarking grammar. Language, 62, 56-119.

Osgood, Ch. E., and Katherine, J. B. (1977). Salience and sentencing: Some production principles. In Sh. Rosenberg (Ed.), Sentence Production (pp. 89-140). New York, NY: Lawrence Erlbaum Associates,.

Palmer, F. R. (1994). Grammatical roles and relations. Cambridge, UK: Cambridge University Press.

Pentland, D. H. (2006). Algonquian and Rittwan languages. In K. Brown and S. Ogilvie (Eds.), Concise Encyclopedia of Languages of the World (pp. 24-29). Amsterdam, Netherlands: Elsevier.

Rákosi, G. (2006). On the need for a more refined approach to the argument-adjunct distinction: The case of dative experiencers in Hungarian. In M. Butt and T. H. King (Eds.), Proceedings of the LFGO6 Conference (pp. 416-436). Konstanz, Germany: CSLI Publications.

Randolph, V. J. (2001). Nishnaabemwin reference grammar. Toronto, Canada: University of Toronto Press.

Salmons, J. (1992). Diachronic typology and tone-to- stress shift. The Journal of Indo-European Studies, 20(3-4), 269-281.

Salzmann, Z. (1963). A sketch of Arapaho grammar (Unpublished doctoral dissertation). Indiana University, Bloomington, IN.

Salzmann, Z. (1983). Dictionary of contemporary Arapaho usage. In W. J. C'Hair (Ed.), Arapaho Language and Culture Instructional Materials Series (Vol. 4). Wind River Reservation, Wyoming. Ethete, WY: Wyo.

Schachter, P. (1976). The subject in Philippine languages: Topic, actor, actor-topic, or none of the above. In Chю N. Li (Ed.), Subject and topic (pp. 491518). New York, NY: Academic Press.

Sgall, P., Hajičová, E., and Benešová, E. (1973). Topic, focus and generative semantics. Kronberg, Germany: Scriptor.

Shields, R. (2004). Word order and discourse in Menominee. In H. C. Wolfart (Ed.), Papers of the $35^{\text {th }}$ Algonquian Conference (pp. 373-388). Winnipeg, Canada: University of Manitoba.

Stacy, E. (2004). Phonological aspects of Blackfoot prominence (Unpublished doctoral dissertation). University of Alberta, Alberta, Canada.

Standop, E. (2000). English verb complementation. Anglia, 118(2), 217-257.

Taylor, A. R. (1969). A grammar of Blackfoot (Unpublished doctoral dissertation). University of California, Berkeley, CA.

Taylor, A. R. (1994). Gros Ventre dictionary. Retrieved from: http://www.ancollege.edu/library/images/ Gros_Ventre_Student_Dictionary.pdf

Tesnière, L. (1969). Éleménts de syntaxe structural [Elements of structural syntax] $\left(2^{\text {nd }}\right.$ ed.). Paris, France: Klincksieck.

Tomlin, R. S., \& Rhodes, R. A. (1992). Information distribution in Ojibwa. Pragmatics of word order flexibility, 22, 117135.

Trubetzkoy, N. S. (1939). Principles of phonology (Ch. A. M. Baltaxe, Trans.). Berkeley, CA: University of California Press.

Uhlenbeck, Ch. C. (1978). A concise Blackfoot grammar based on material from the southern Peigans. New York, NY: AMS.

van der Hulst, H. G., \& Smith, N. (1988). The variety of pitch-accent systems. In H. G. van der Hulst \& N. Smith (Eds.), Autosegmental studies on pitch accent (pp. 1-14). Dordrecht, Netherlands: Foris.

van der Hulst, H. G. (1999). Word accent. In H. G. van der Hulst (Ed.), Word prosodic systems in the languages of Europe (pp. 3-116). Berlin, Germany: Mouton de Gruyter.

van der Hulst, H. G. (2010). Word accent: Terms, typologies and theories. In H. G. van der Hulst, R. Goedemans and E. van Zanten (Eds.), A survey of word accentual patterns in the languages of the world 


\section{AVELINO CORRAL ESTEBAN}

(pp. 3-53). Boston, MA: De Gruyter Mouton.

van der Mark, Sh. (2001). The acoustic correlates of Blackfoot prominence. Calgary Working Papers in Linguistics, 24, 169-216.

van der Mark, Sh. (2003). The phonetics of Blackfoot pitch accent (Unpublished MA thesis). University of Calgary, Calgary, Canada.

van Valin, R. D. Jr. (1993). A synopsis of role and reference grammar. In R. D. van Valin Jr. (Ed.), Advances in Role and Reference grammar (pp.1-164). Amsterdam, Netherlands: John Benjamins.

van Valin, R. D. Jr. (2000). A concise introduction to role and reference grammar. Fluminensia: Journal for Philological Research, 12(1-2), 47-78.

van Valin, R. D. Jr. (2005). Exploring the syntax-semantics interface. Cambridge, UK: Cambridge University Press.

van Valin, R. D. Jr., \& LaPolla, R. J. (1997). Syntax: Structure, meaning and function. Cambridge, UK: Cambridge University Press.

Wolfart, H. Ch. (1973). Plains cree: A grammatical study. Transactions of the American Philosophical Society, New Series, 63, 5.Yip, M. (2002). Tone: Cambridge textbooks in Linguistics. Cambridge, UK: Cambridge University Press. 